\title{
The genetic causes of male infertility: a Middle East and North
}

\section{Africa perspective [version 1; peer review: 2 approved with}

\section{reservations]}

\author{
Ruthwik Duvuru(iD1, Mouhammad Halabi², Temidayo S. Omolaoye (iD), \\ Stefan S. Du Plessis ${ }^{1,3}$ \\ ${ }^{1}$ College of Medicine, Mohammed Bin Rashid University of Medicine and Health Sciences, Dubai Health Care City, Dubai, 505055, \\ United Arab Emirates \\ ${ }^{2}$ School of Medicine, Royal College of Surgeons, Ireland-Bahrain, Busaiteen, Bahrain \\ ${ }^{3}$ Division of Medical Physiology, Faculty of Medicine and Health Sciences, Stellenbosch University, Cape Town, Western Cape, 7505, \\ South Africa
}

V1 First published: 31 Jan 2022, 11:125

https://doi.org/10.12688/f1000research.106950.1

Latest published: 06 Jun 2022, 11:125

https://doi.org/10.12688/f1000research.106950.2

\section{Abstract}

Male infertility is attributable to $50 \%$ of total infertility cases and about $30 \%$ of these cases remain idiopathic. In the Middle East and North Africa region (MENA), male infertility affects about $22.6 \%$ of men of reproductive age. Male infertility is caused by a variety of factors, including endocrine disruption, exposure to toxins, lifestyle, genetic and epigenetic modifications. Genetic modifications, including chromosomal abnormalities, chromosomal rearrangements, $Y$ chromosome microdeletions and single-gene mutations, explain for about $10-15 \%$ of infertility cases. Since genetic aberration is a key player in the pathogenesis of male infertility, it is important to explore the impact in the MENA region due to the high incidence of male infertility. Therefore, the current study aims to systematically analyse the literature regarding the impact and common causes of male infertility in the MENA region. To achieve this aim, a comprehensive literature search was performed on PubMed, Google Scholar, and Science Direct databases. Following the search, a total of 126 articles was retrieved, of which 12 were duplicates and another 69 articles did not meet the inclusion criteria, totaling the exclusion of 81 articles. Studies excluded were those that had patient populations originating outside the MENA region, review articles, non-English written articles, or studies where the patient population was under 18 years of age. Findings showed that the frequent genetic aberration leading to male infertility in these regions include $Y$ chromosome microdeletions, gene polymorphisms or copy number variations, mitochondrial microdeletions and other genetic deletions or mutations. In lieu of this, diverse clinical genetic tests should be made available for the proper diagnosis of male infertility.

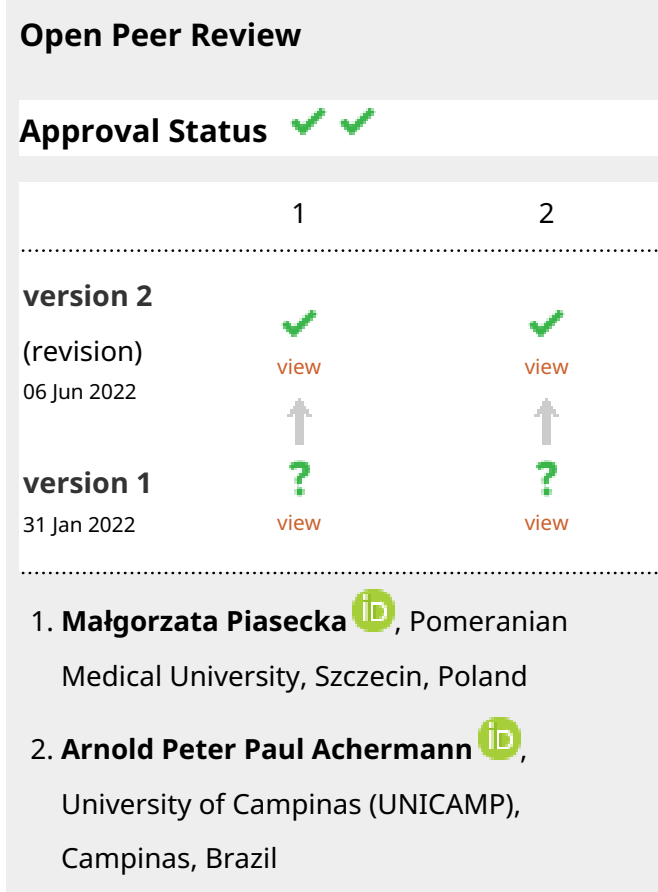

Any reports and responses or comments on the article can be found at the end of the article. 


\section{Keywords}

male infertility, chromosomal abnormalities, MENA, gene deletion, gene mutation; $Y$ chromosome microdeletion.

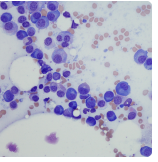

This article is included in the Cell \& Molecular

Biology gateway.

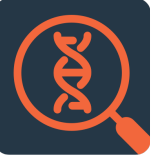

This article is included in the Genomics and

Genetics gateway.

Corresponding author: Temidayo S. Omolaoye (temidayo.omolaoye@mbru.ac.ae)

Author roles: Duvuru R: Data Curation, Investigation, Writing - Original Draft Preparation; Halabi M: Data Curation, Investigation, Writing - Original Draft Preparation; Omolaoye TS: Conceptualization, Investigation, Supervision, Writing - Review \& Editing; Du Plessis SS: Conceptualization, Supervision, Writing - Review \& Editing

Competing interests: No competing interests were disclosed.

Grant information: This project was partially supported by the Al Jalila Foundation.

The funders had no role in study design, data collection and analysis, decision to publish, or preparation of the manuscript.

Copyright: @ 2022 Duvuru R et al. This is an open access article distributed under the terms of the Creative Commons Attribution License, which permits unrestricted use, distribution, and reproduction in any medium, provided the original work is properly cited.

How to cite this article: Duvuru R, Halabi M, Omolaoye TS and Du Plessis SS. The genetic causes of male infertility: a Middle East and North Africa perspective [version 1; peer review: 2 approved with reservations] F1000Research 2022, 11:125

https://doi.org/10.12688/f1000research.106950.1

First published: 31 Jan 2022, 11:125 https://doi.org/10.12688/f1000research.106950.1 


\section{Introduction}

Infertility represents the inability to achieve pregnancy after twelve or more months of regular unprotected sexual intercourse, and it affects about $15 \%$ of couples of reproductive age. Of the total cases, $50 \%$ are attributable to the male factor (Vander Borght and Wyns 2018). Not until recently, infertility represented a reproductive health disorder that was neglected, especially in the MENA region. In 2012, Mascarenhas et al. reported that infertility prevalence was highest in South Asia, Sub-Saharan Africa, North Africa and the Middle East, Central/Eastern Europe and Central Asia (Mascarenhas et al. 2012). Six years later, Eldib and Tashan (2018) showed that the incidence of primary infertility (inability to conceive after 12 or more months of regular unprotected sexual intercourse) in the Middle East and North Africa region (MENA) region is estimated at 3.8\%, and secondary infertility (incapacity to conceive after 5 years of previous live birth) at $17.2 \%$, while demographic infertility (failure to achieve conception with live birth within 5 years of exposure, based on a consistent union status, lack of contraceptive use, non-lactating and maintaining a desire for a child (Mascarenhas et al. 2012)) is estimated at 22.6\% (Eldib and Tashani 2018). Recently, Sun et al. reported that the global age-standardized prevalence of infertility has increased by $23.184 \%$, with the prevalence of male infertility estimated at $8.224 \%$. The variations in the prevalence of male infertility across different populations were also noted (Sun et al. 2019). The Western Sub-Saharan African population have the highest rates of age-standardized male infertility at 1800 infertile men per 100,000, whereas Australasia has the lowest rates, approximately 200 infertile men per 100,000 (Sun et al. 2019). According to the same study, infertility rates in the MENA region are well above Central Europe, Western Europe, SouthEast Asia amongst several others at 800 infertile men per 100,000. Out of the three countries that presented with an increase in the trend of male infertility, two are from the MENA region. One is from the Middle East (Turkey; 1.498\%) and the other is from North Africa (1.676\%) (Sun et al. 2019). Since demographic infertility in the MENA region is on the high side (Eldib and Tashani 2018), and as well as the trend in male infertility (Sun et al. 2019), it is of utmost importance to investigate the causes.

Utilizing the World Health Organization diagnostic classification for male infertility (Organization 2018), studies have elucidated azoospermia, oligozoospermia, asthenozoospermia, teratozoospermia, or combinations thereof, as part of the causes of male infertility (Ikechebelu et al. 2003, Punab et al. 2017). A study conducted in Turkey revealed that $32 \%$ of the infertility cases was due to the male factor, who were either azoospermic or oligozoospermic (Karabulut et al. 2018). Even with the discovery of different causes of male infertility using semen analysis, diagnosing male infertility is complex due to a wide variety of genetic aberrations associated with the condition.

During the past decade, genetic studies have made great progress in elucidating the causes of male infertility, which include chromosomal translocations, azoospermia factor (AZF) deletions, Klinefelter syndrome, cystic fibrosis, and Noonan syndrome (Elsawi et al. 1994, Okada et al. 1999, Sokol and Shapiro 2001, Dhanoa et al. 2016, Kuroda et al. 2020). Some studies have identified chromosomal translocations as the most common structural genetic aberration seen in men, with nearly 1.23 per 1000 (Chen 2007, Kuroda et al. 2020). Until recently, genetic testing for chromosomal aberrations and AZF deletions are the only ways to come to a conclusive diagnosis of genetic abnormality induced male infertility. The optimal treatment plans for treating idiopathic male infertility have remained unclear unlike for established conditions such as hypogonadotropic hypogonadism and retrograde ejaculation. In order to get more informed about the genetic causes of male infertility, especially in the MENA region, the current study aimed to analyse the literature extensively regarding the effect, and the common genetic aberrations leading to male infertility from the MENA region perspectives. The epidemiological relevance of genetic anomalies induced male infertility was also discussed.

\section{Literature search}

To explore the common genetic aberrations in the MENA region, a thorough literature search was performed following the methodology of the Preferred Reporting Items for Systematic reviews and Meta-Analysis (PRISMA) guidelines. Since the MENA countries include Algeria, Bahrain, Egypt, Iran, Iraq, Israel, Jordan, Kuwait, Lebanon, Libya, Morocco, Oman, Palestine, Qatar, Saudi Arabia, Syria, Tunisia, Turkey, United Arab Emirates, and Yemen, the search terms integrated each country with other parameters, such as "male infertility", and "genetic alteration". The literature search was performed on PubMed, Google Scholar, and Science Direct databases, retrieving articles that included male patients above the age of 18 from the MENA region, and research articles published between 1999 and 2020.

Following the search, a total of 126 articles was retrieved, of which 12 were duplicates and another 69 articles did not meet the inclusion criteria. Studies excluded were those that had patient populations originating outside the MENA region, review articles, non-English written articles, or studies where the patient population was under 18 years of age (Figure 1).

Forty-five studies met the inclusion criteria and are reported in the current study (Table 1). After analysing the 45 studies, 24 were performed in Iran, 14 in Turkey, 4 in Saudi Arabia, 2 from Tunisia and 1 in Iraq. Represented in Figure 2 is the distribution of MENA studies according to the genetic abnormalities. From our findings, the following are the common 


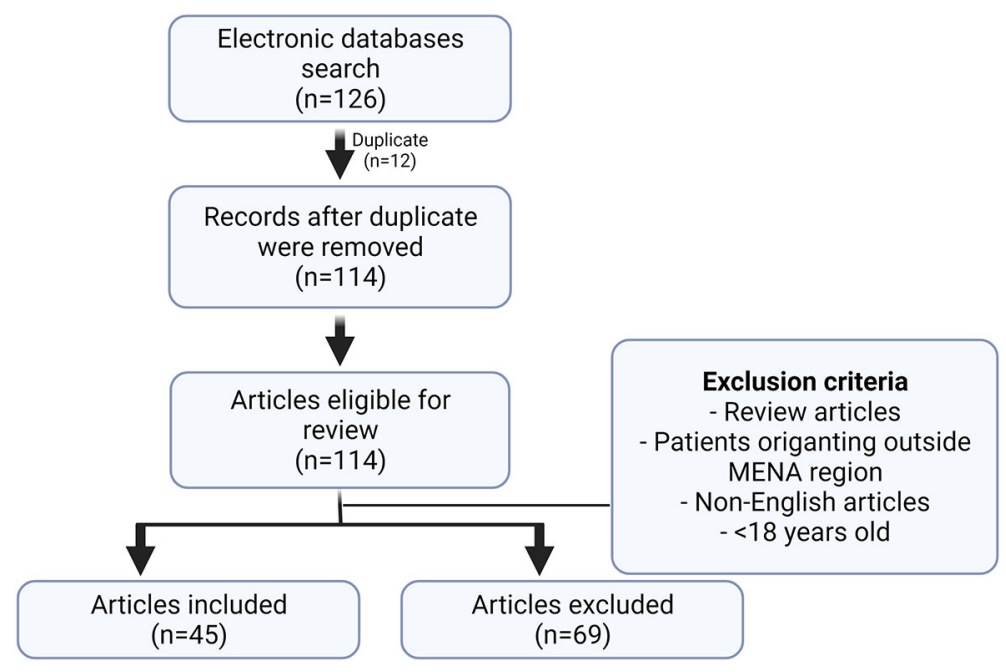

Figure 1. Schematic representation of the search method. Following the search from different databases, a total of 126 articles was retrieved, of which 12 were duplicates and another 69 articles did not meet the inclusion criteria. Studies excluded were those that had patient populations originating outside the MENA region, review articles, nonEnglish written articles, or studies where the patient population was under 18 years of age.

genetic abnormalities found in the MENA region: (i) $\mathrm{Y}$ chromosome microdeletion, (ii) deletion or gene mutation, (iii) gene polymorphism or copy number variations, (iv) chromosomal disorders, and (v) mitochondrial mutation. The findings will be discussed under these headings.

\section{Y chromone microdeletion}

One of the most common genetic aberrations contributing to infertility is $\mathrm{Y}$ chromosome microdeletion. The $\mathrm{Y}$ chromosome is one of two sex chromosomes available within the human genome. Structurally, the Y chromosome is composed of a short arm (Yp) and a long arm (Yq) (Ferlin et al. 2006, Gurkan et al. 2013). The long arm of the Y chromosome is made of repetitive elements that leave individuals at a high risk of internal recombination and segmental deletions. The function of the $\mathrm{Y}$ chromosome is to drive gonadal differentiation and develop the male phenotype (Gurkan et al. 2013).

Y chromosomal microdeletions can arise in the $\mathrm{P}$ or $\mathrm{Q}$ arm of the chromosome. If it arises in the $\mathrm{p}$ arm, it directly disturbs the differentiation of the testis. Y chromosome microdeletions in the AZF region of the $\mathrm{q}$ arm may lead to infertility. The AZF region is made up of multiple genomic loci, including AZFa, AZFb, AZFc, AZFd. These regions are believed to be responsible for spermatogenesis (Gurkan et al. 2013).

Located in the AZFa region is Ubiquitin specific peptidase 9 Y linked (USP9Y), which plays an important role in male reproductive development and spermatogenesis (Colaco and Modi 2018), as studies have shown its absence in infertile men whilst also noting its lack even in normal sperm count fertile men (Colaco and Modi 2018). Dead Box RNA Helicases, Box 3, Y linked ( $D B Y$ ), another functional gene in the AZFa region, encodes an ATP-dependent DEAD-box RNA helicase that is only expressed in germ cells. It has a homologue on the $\mathrm{X}$ chromosome $(D B X)$ with $95 \%$ similarity, with the former playing a role limited to pre-meiotic male germ cells and the latter on post-meiotic spermatids. Males who did not have the DBY gene exhibited either Sertoli Cell only Syndrome (SCOS) or severe hypospermatogenesis, suggesting the gene's importance in spermatogenesis (Foresta et al. 2000, Stanton et al. 2012). The functional genes seen in AZFb include Ribosomal protein S4, Y linked (RPS4Y2), which is expressed in the testis and prostate (Stahl et al. 2012). It plays a vital role in post-transcriptional regulation of the spermatogenic process. The Heat Shock Transcription Factor, Y linked (HSFY), exists as two coding copies in AZFb, HSFY1 and HSFY2. HSFY is predominantly present in the nuclei of round spermatids and is also associated with spermatogenesis (Stahl et al. 2012). One of the most important genes located in the AZFb region with 6 copies is the Ribonucleic Acid Binding Motif, Y linked (RBMY) and it is responsible for the regulation of alternating splicing during spermatogenesis (Poongothai et al. 2009). Deleted in Azoospermia $(D A Z)$ genes are located in the AZFc region and have autosomal homologues. There are palindromic duplications of $D A Z$. These sequences together encode an RNA-binding protein vital for spermatogenesis. Infertile males with loss of DAZ seem to be highly predisposed to azoospermia and oligozoospermia (Al-Janabi et al. 2020). Albeit that the presence of $D A Z$ deletions in both fertile and infertile men question its importance, the former although fertile have lower sperm counts and reduced sperm motility. Basic protein Y linked 2 (BSY2) is expressed in the testis and it is 


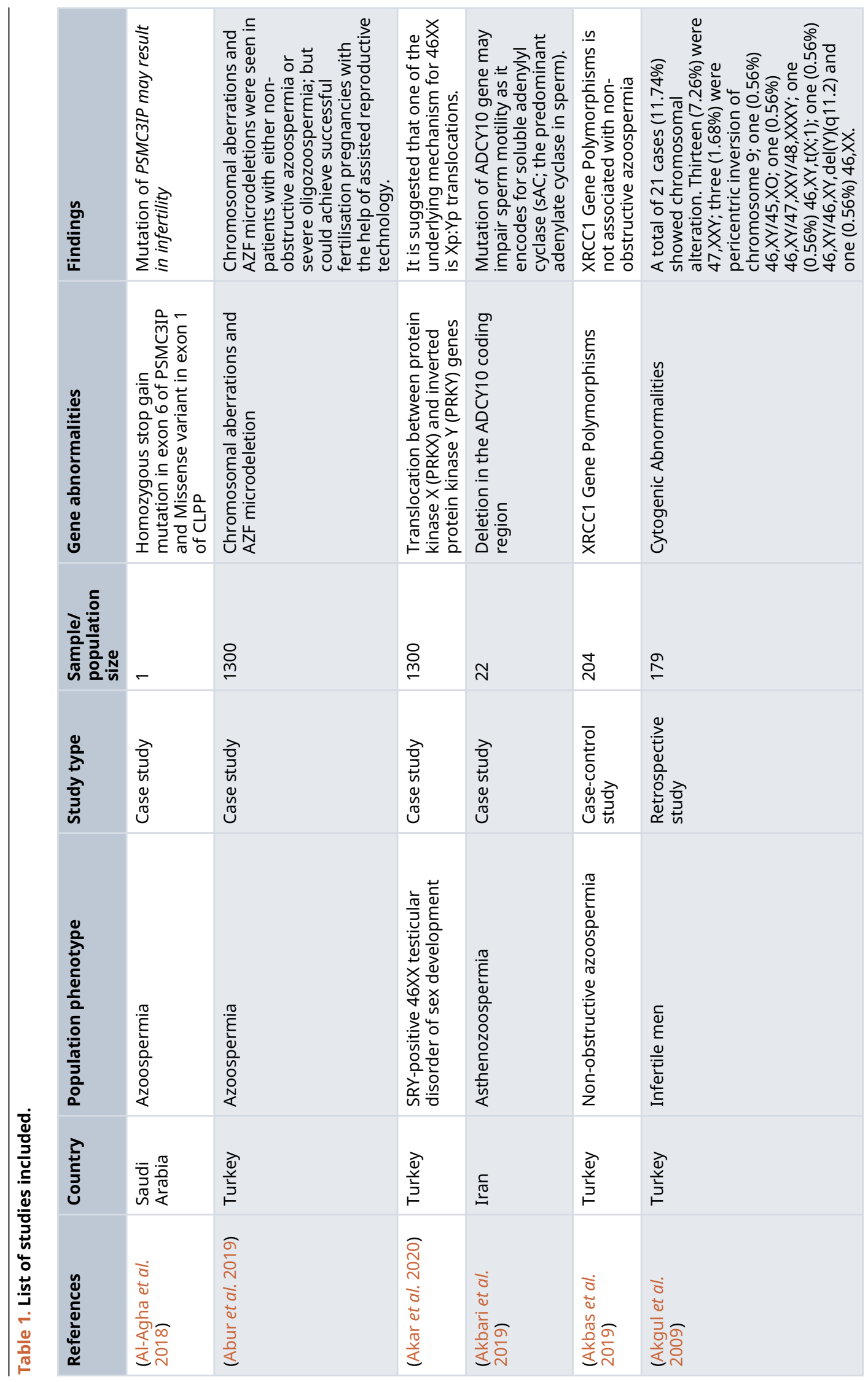




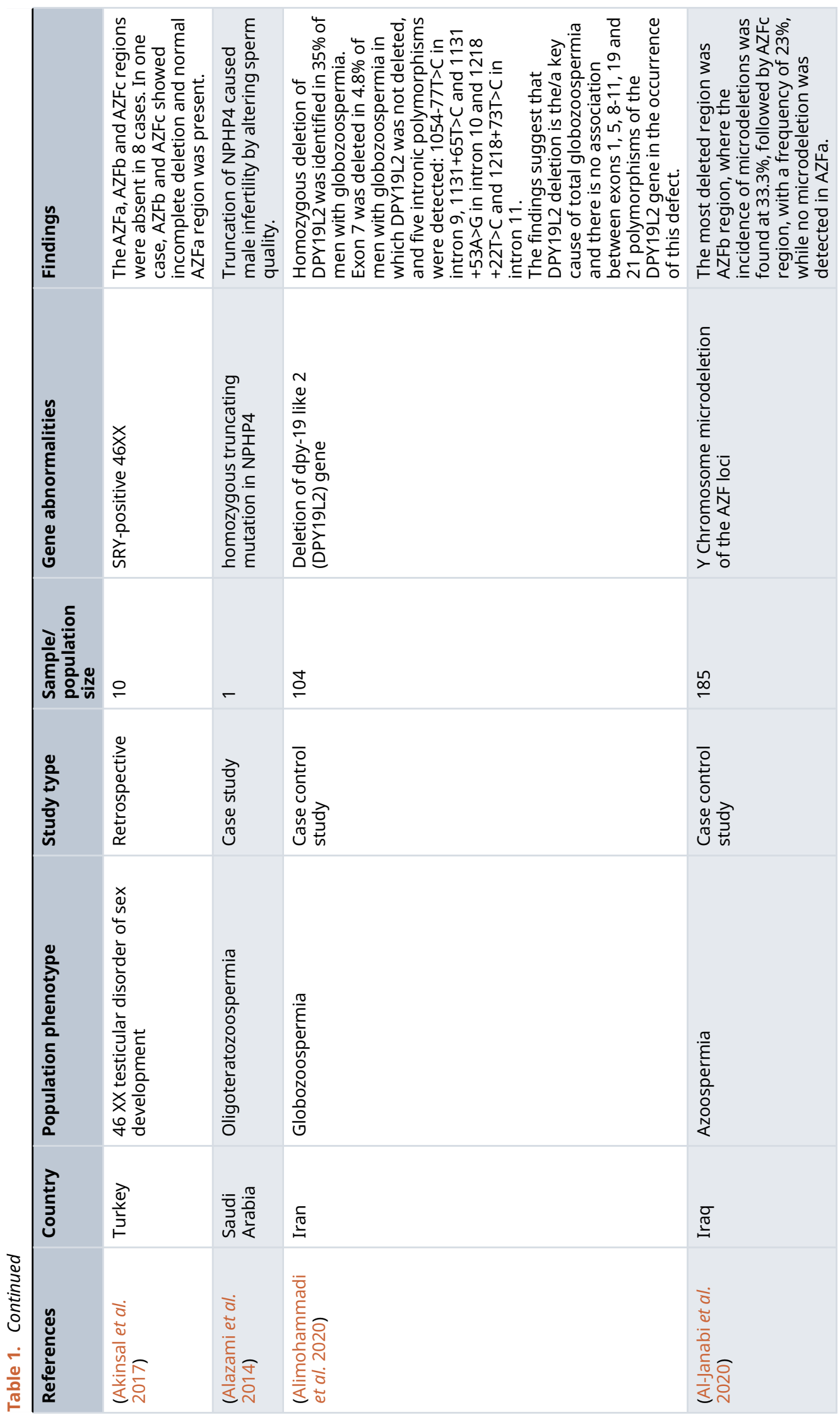




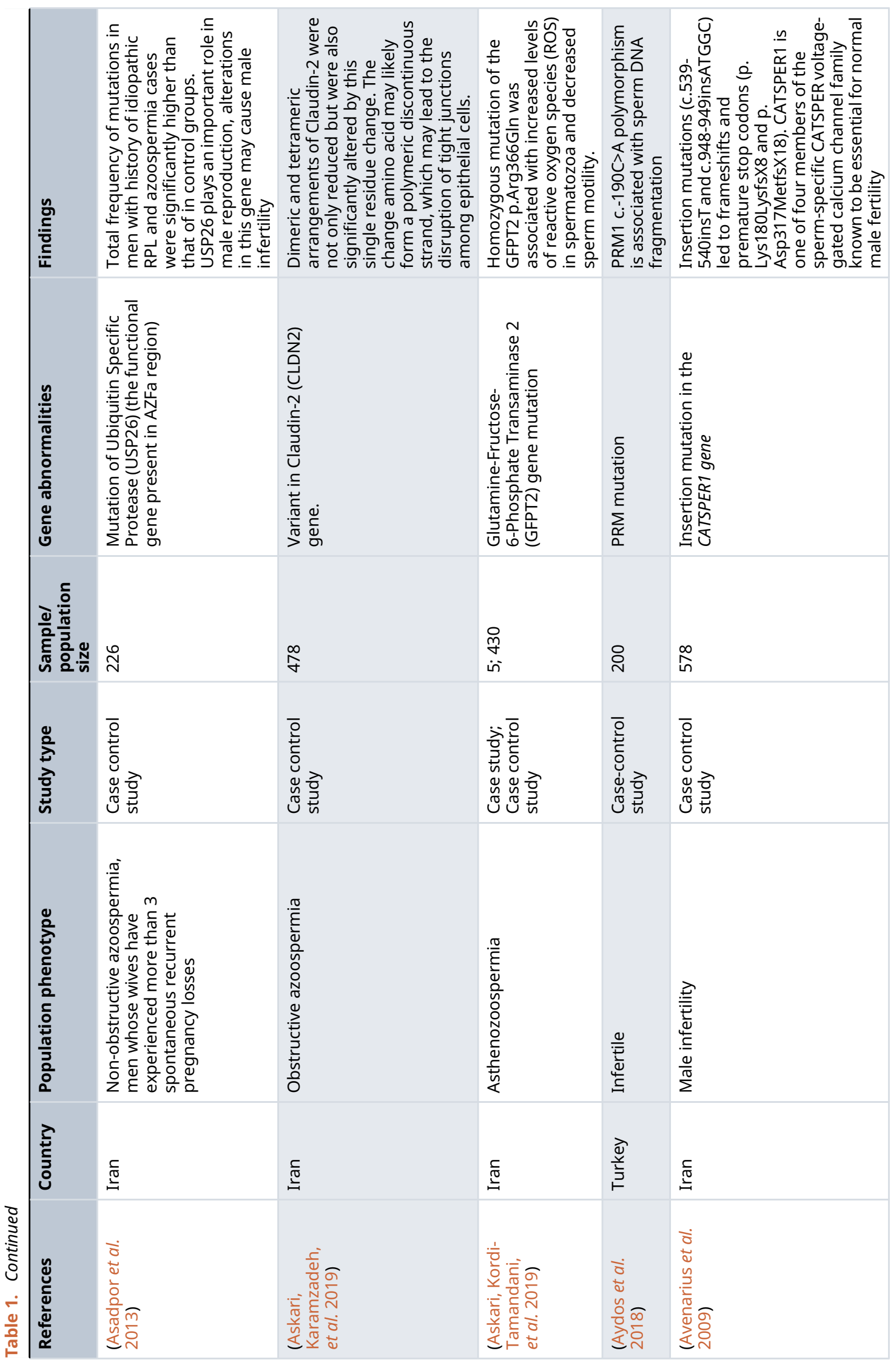




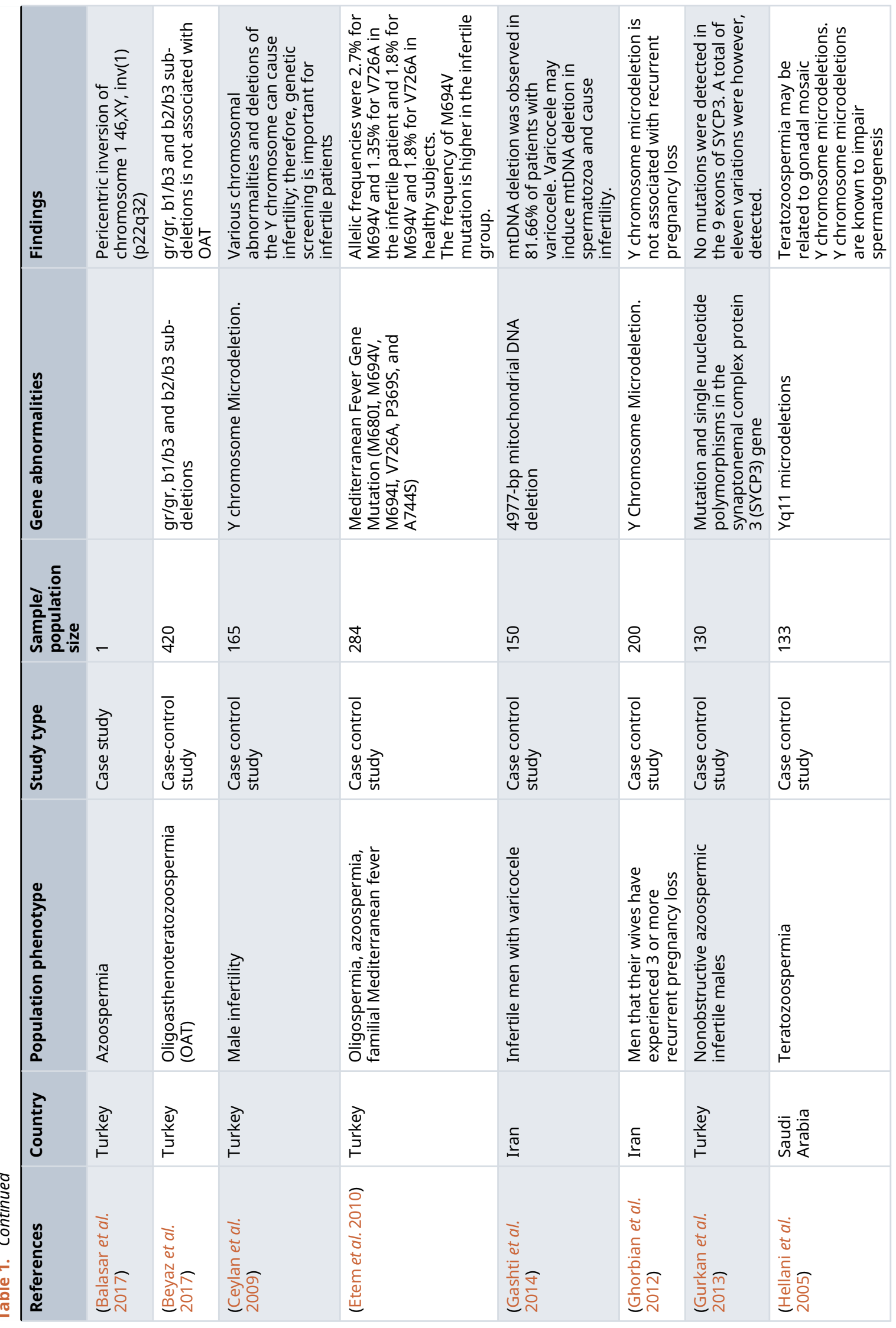




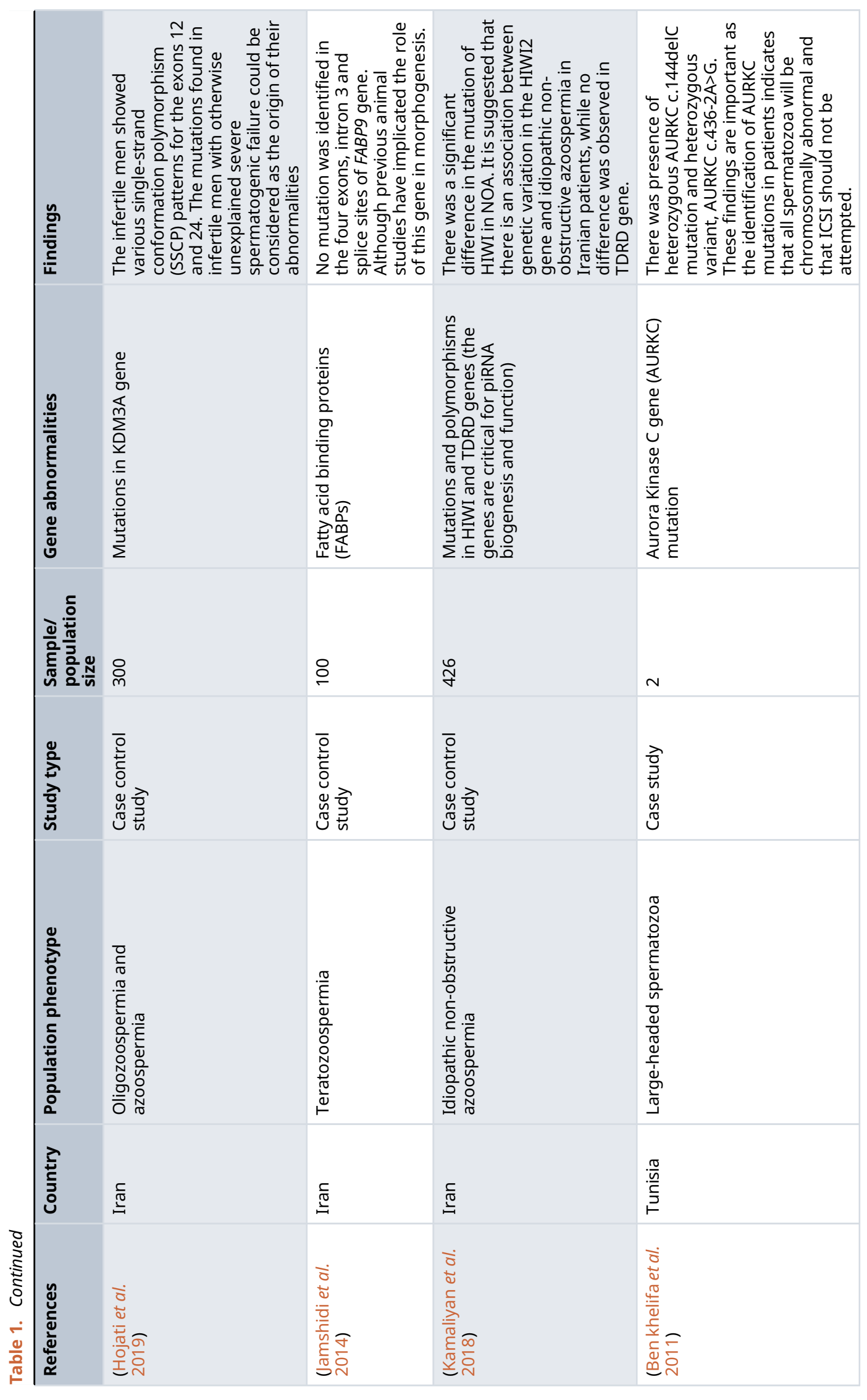




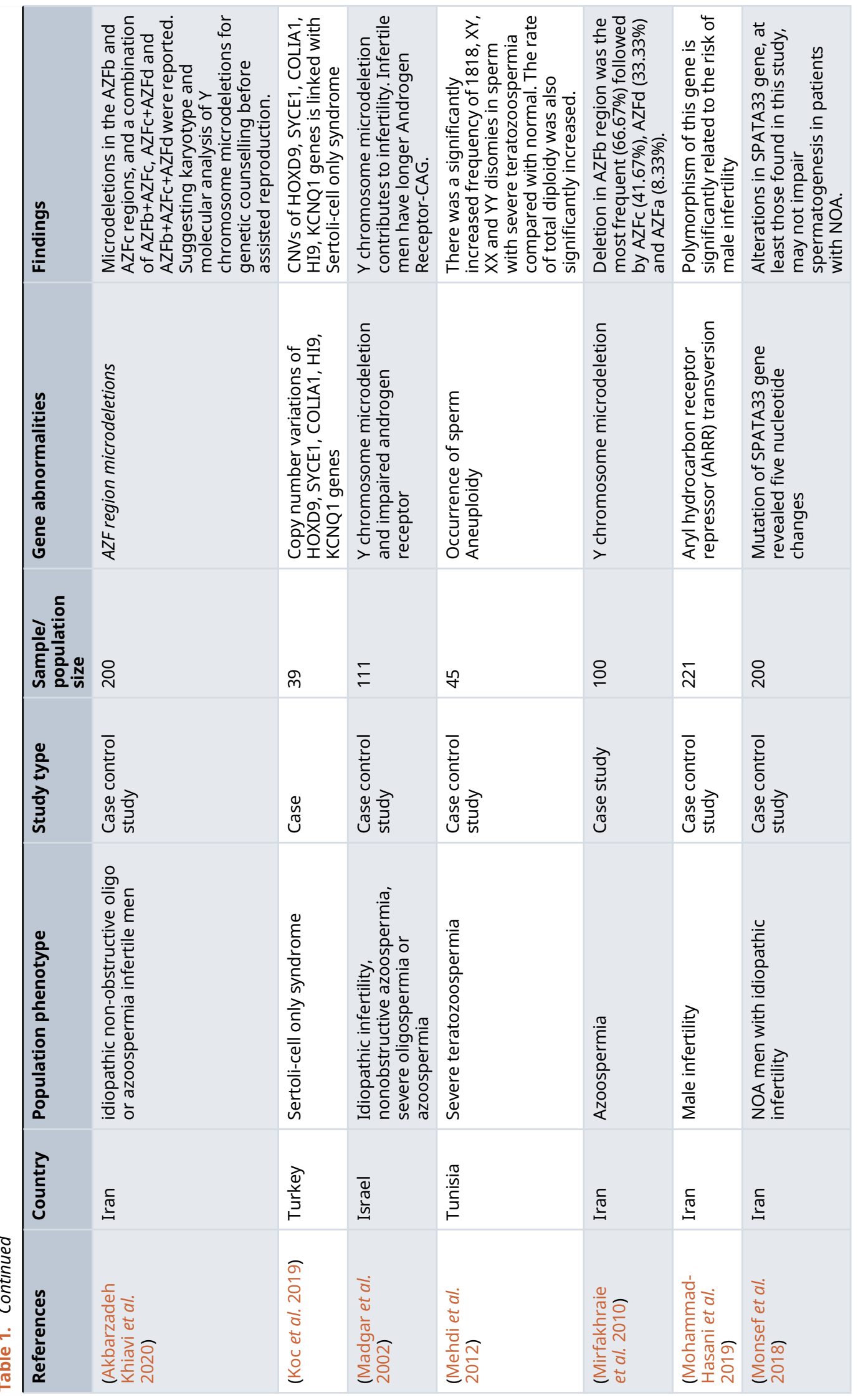




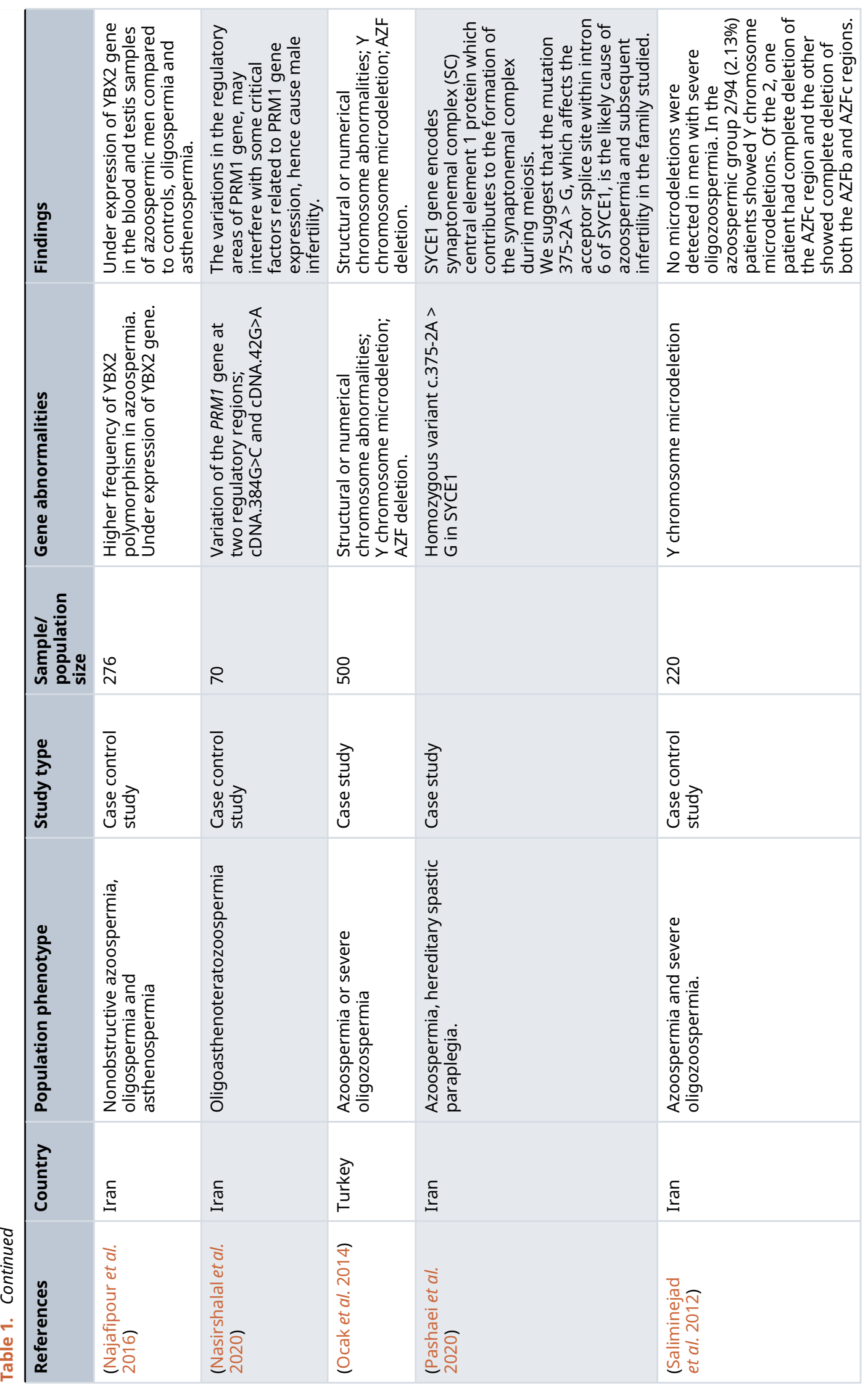




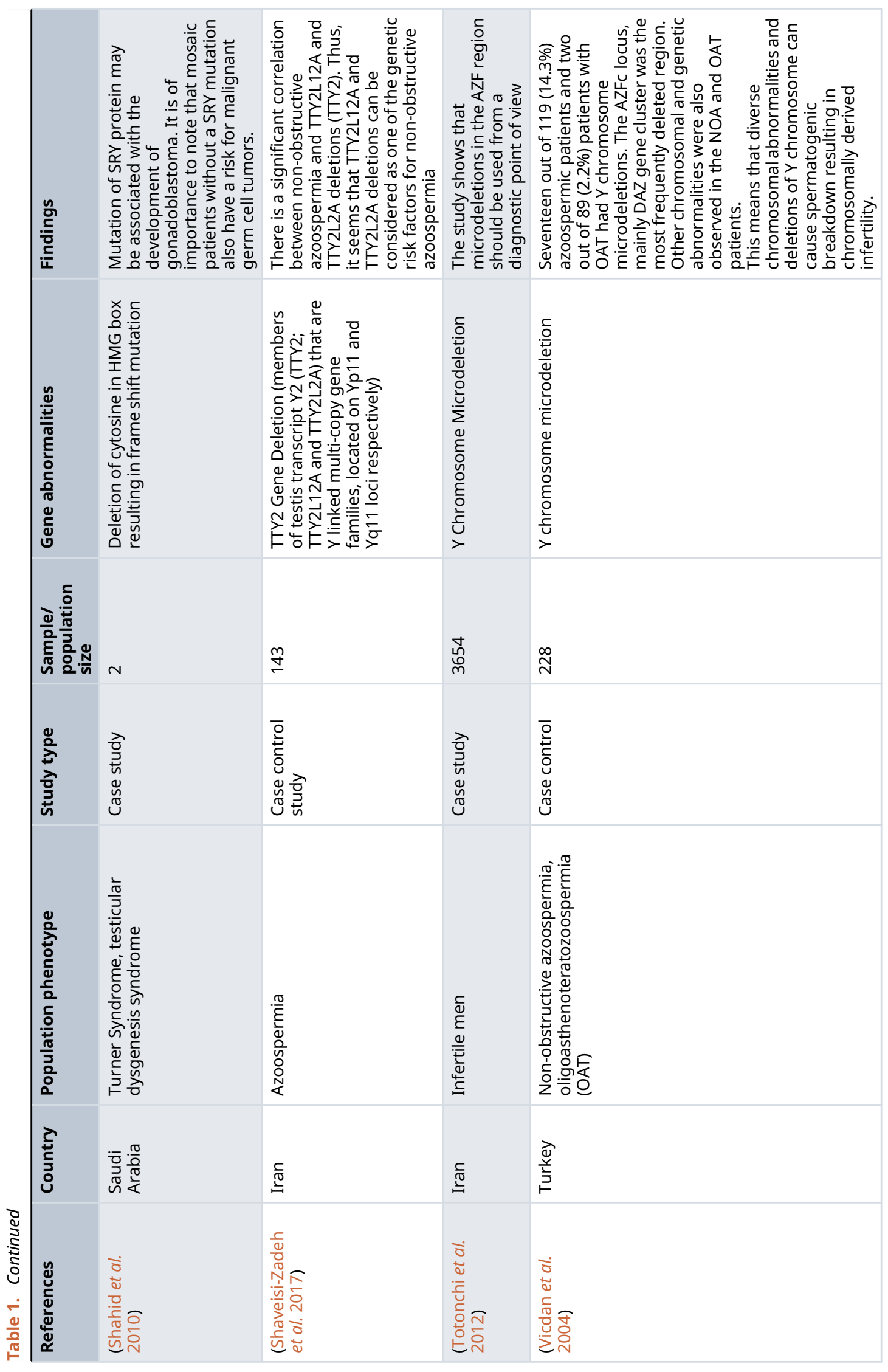




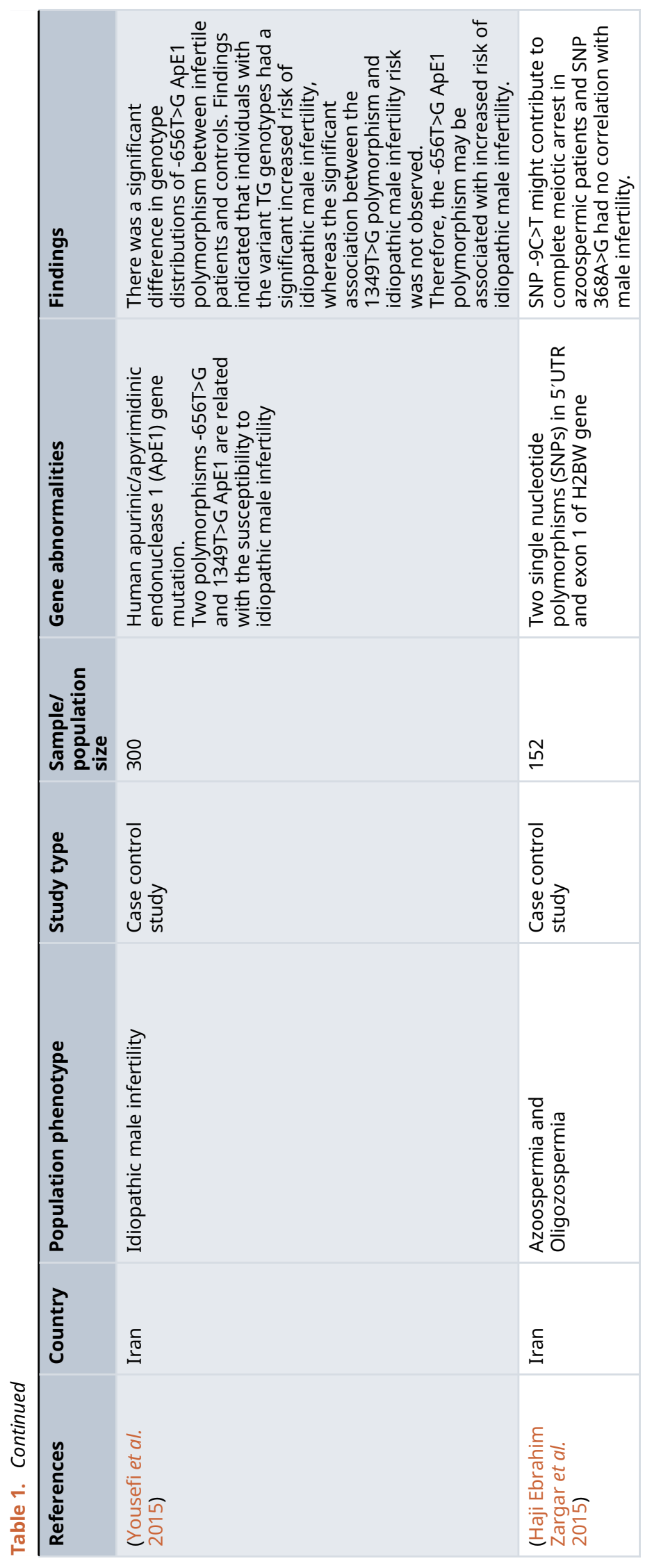




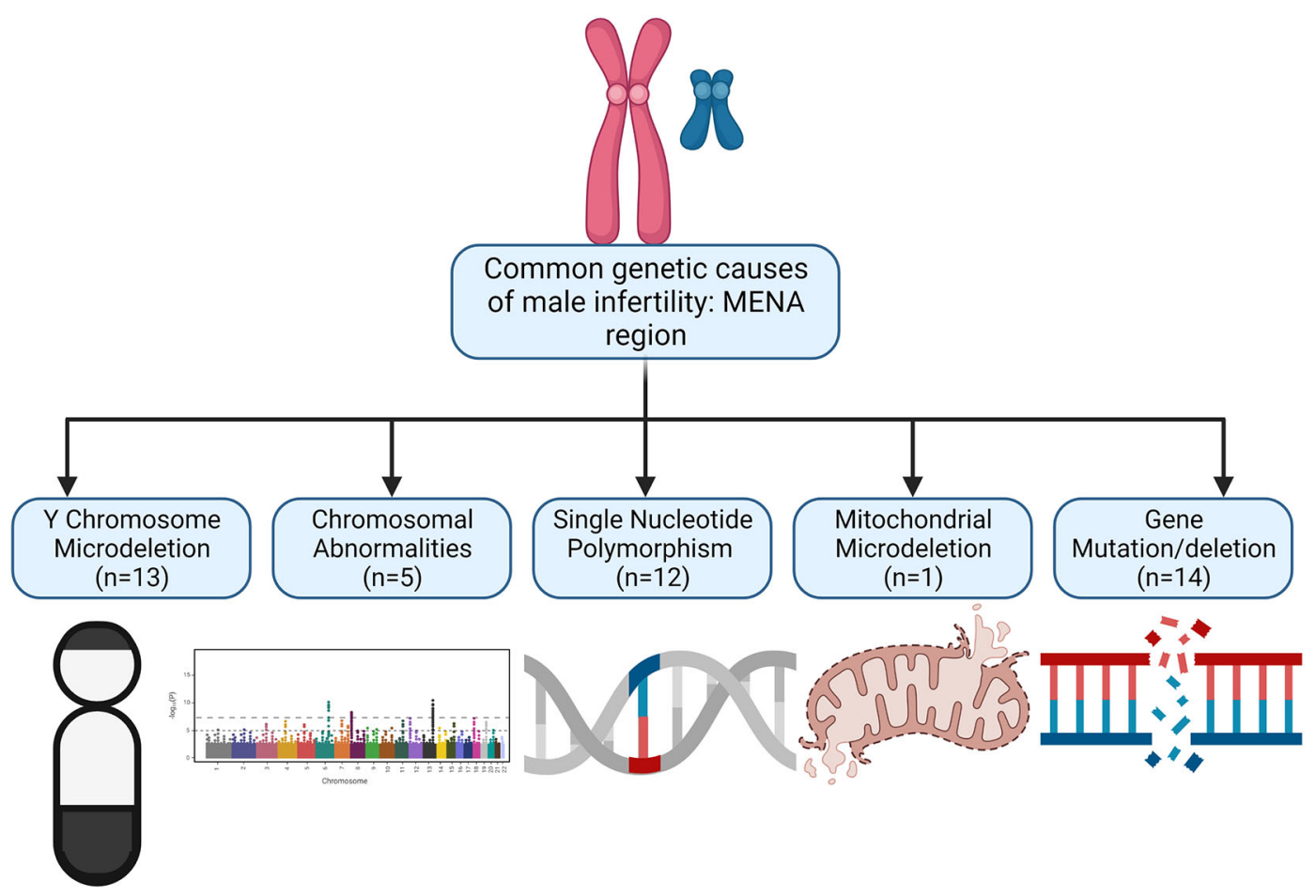

Figure 2. Distribution of MENA studies according to the genetic alteration the genetic alteration. From our findings, the following are the common genetic abnormalities found in the MENA region: (i) Y chromosome microdeletion, (ii) deletion or gene mutation, (iii) gene polymorphism or copy number variations, (iv) chromosomal disorders, and (v) mitochondrial mutation.

implicated in the process of male germ cell development. This gene is hypothesized to be involved in the cytoskeletal regulation of spermatogenesis. Testis specific protein is a multicopy gene that is only expressed in the testis and is possibly responsible for germ cell proliferation (Ceylan et al. 2009, Dhanoa et al. 2016).

\section{Evidence of $Y$ chromosome microdeletion in the MENA region}

Across the different populations of the MENA region, studies have elucidated the role of $\mathrm{Y}$ chromosome microdeletion in male infertility (Madgar et al. 2002, Vicdan et al. 2004, Hellani et al. 2005, Ceylan et al. 2009, Mirfakhraie et al. 2010, Ghorbian et al. 2012, Saliminejad et al. 2012, Totonchi et al. 2012, Mohammad-Hasani et al. 2019, Akbarzadeh Khiavi et al. 2020, Al-Janabi et al. 2020). The summary of these findings is presented in Table 1. A study carried out in Turkey by Vicdan et al. (2004) reported that of 208 infertile male patients, 119 had obstructive azoospermia (OA), and 89 had severe oligoasthenoteratozoospermia (OAT). Seventeen out of 119 OA patients and two out of 89 patients with OAT had Y chromosome microdeletion (Vicdan et al. 2004), with the DAZ gene of the AZFc locus being the most frequently deleted. In total, 19 cases of Y chromosome microdeletion were detected in 208 infertile men, and chromosomal abnormalities were observed in another 5 non-obstructive azoospermia (NOA) (4.2\%), and 2 OAT cases (2.2\%). Of which these genetic abnormalities were not seen in the fertile men. It was also added that $\mathrm{Y}$ chromosome microdeletion and chromosomal abnormalities are associated with various histological alterations in the testes, such as SCOS and maturation arrest, while hypospermatogenesis occurred often in genetically normal patients.

The study conducted by Saliminejad et al. (2012) in Iran examined a total of 115 infertile male patients, 94 had azoospermia and 21 had severe oligozoospermia. Both patient groups were examined for Y chromosome microdeletions. Of the 94 patients with azoospermia, none had Y chromosome microdeletions, and of the 21 patients with severe oligospermia two patients were reported to have $\mathrm{Y}$ chromosome microdeletions. One of the patients had a deletion in the AZFc locus and the other had a deletion in the AZFb and AZFc loci (Saliminejad et al. 2012). The frequency of Y chromosome microdeletion occurrence in this study is relatively low compared to other reports from the MENA region (Vicdan et al. 2004, Al-Janabi et al. 2020).

Another study carried out in Turkey by Ceylan et al. (2009) reported that of the 90 infertile male patients with severe male infertility, 30 patients had NOA, 30 had oligozoospermia, and 30 were normozoospermic. Y chromosome microdeletions 
were present in five of the 30 patients with NOA, four of the thirty with oligospermia, and two of the normozoospermic patients. They also reported that among these patient groups the most commonly deleted $\mathrm{Y}$ chromosome region was the AZFc locus (Ceylan et al. 2009). Chromosomal abnormalities were also seen in another 10 NOA, four oligozoospermic patients and four normozoospermic infertile men, while the 75 recruited fertile men had no deletions or chromosomal abnormalities. This shows that genetic aberration, especially $\mathrm{Y}$ chromosome microdeletion may be involved in idiopathic male infertility.

Hormonal aspects of Y chromosome microdeletion were reported by Mostafa et al. (2020) in the Iranian population. Levels of follicle-stimulating hormone (FSH) and luteinizing hormone ( $\mathrm{LH}$ ) were evaluated in fertile and infertile patients. They noted that the levels of FSH and LH were higher in Infertile men than that of their fertile counterparts, this may also serve as a reliable marker for epithelial damage, azoospermia, and Oligospermia. Additionally, high levels of testosterone and thyroid-stimulating hormone may serve as primary markers for primary testicular failure (Akbarzadeh Khiavi et al. 2020).

Al-Janabi et al. (2020) reported that the most common region that microdeletion occurred in the sampled Iraqi population is the $\mathrm{AZFb}$ region, where the incidence of microdeletion was found at 33.3\%. The next most common region that microdeletion occurred was the AZFc region, with a frequency of $23 \%$. No microdeletion was reported in the AZFa region (Al-Janabi et al. 2020).

Deducing from these findings, it is evident that $\mathrm{Y}$ chromosome microdeletion can cause several testicular dysfunctions, such as SCOS, and maturation arrest (pre- and post-meiotic), which can lead to hypospermatogenesis, NOA or OAT. Hence, the importance of testing for Y chromosome microdeletion in men experiencing idiopathic infertility should be promoted in the MENA region.

\section{Genetic mutations}

Genes control a variety of physiological processes, including reproductive developments. Spermatogonial stem cells must undergo a variety of processes before becoming fully matured spermatozoa; these phases are controlled by genes. Any variation in genes that contribute to sperm maturation may lead to infertility.

Genetic abnormalities account for 15-30\% of infertility cases worldwide (Kovac and Alexander W. Pastuszak 2014), hence, identifying and understanding the various genetic mutations is vital. It is important to recognize the genetic basis of infertility to provide better care, as well as an improved prognosis to infertile couples. Several studies have shown how the variation in essential spermatogenesis specific genes led to the impairment of this process and ultimately male infertility (Avenarius et al. 2009, Shahid et al. 2010, Etem et al. 2010, Asadpor et al. 2013, Jamshidi et al. 2014, Alazami et al. 2014, Shaveisi-Zadeh et al. 2017, Al-Agha et al. 2018, Monsef et al. 2018, Akbari et al. 2019, Askari, Karamzadeh, et al. 2019, Askari, Kordi-Tamandani, et al. 2019, Hojati et al. 2019, Alimohammadi et al. 2020). This section will briefly describe some genes that the deletion or mutation thereof led to impaired male fertility.

Evidence of genetic mutations in the MENA region

Glutamine-Fructose-6-Phosphate Transaminase 2

A study done in Iran by Askari et al. (2019) discussed the effects of variation in Glutamine-Fructose-6-Phosphate Transaminase 2 (GFPT2) on fertility. GFPT2 is a rate-limiting enzyme that is responsible for hexosamine biosynthesis. They found that a homozygous missense mutation in the gene led to azoospermia. They also noted that GFPT2 may protect against reactive oxygen species (ROS); ROS may induce the peroxidation of unsaturated fatty acids or phosphorylate axoneme proteins. Both mechanisms eventually lead to decreased sperm motility (Askari, KordiTamandani, et al. 2019).

Lysine demethylase 3A pathway

A study carried out by Hojati et al. (2019) examined the relationship between variation in lysine demethylase 3A $(K D M 3 A)$ and male Infertility. KDM3A is a gene that is believed to be responsible for sperm chromosome condensation. The study reported that various mutations in the KDM3A gene led to infertility in five Iranian males (Hojati et al. 2019). To rule out the common causes of infertility, they also examined $Y$ chromosome microdeletion and partial AZF deletions. Surprisingly, the five patients with variation in $K D M 3 A$ had no $\mathrm{Y}$ chromosome microdeletion or AZF microdeletion. This study proves that a variations in $K D M 3 A$ could lead to spermatogenic failure. They also pointed out that the KDM $3 A$ gene is located on chromosome 2, which can be transferred to the offspring via the genetic pool. This means that the offspring, regardless of gender, could be susceptible to inheriting this type of mutation. 


\section{CATSPER channel protein}

Avenarius et al. (2009) carried out a study to report the relationship between variation in the CATSPER1 channel and infertility amongst Iranian men. The study showed that the CATSPER1 channel protein is responsible for the calcium influx during the hyperactivity phase of sperm after ejaculation. Thus, any variation in this protein channel can disrupt the hyperactivity phase, evidently leading to infertility (Avenarius et al. 2009).

Spermatogenesis associated 33 mutation (SPATA33)

This study performed by Monsef et al. (2018) examined the relationship between variations in SPATA33 and infertility in men with NOA. SPATA33 is highly expressed in the testis, and so it was reasonable to assume that a variation of this gene might lead to infertility. However, it was reported that there is no direct association between SPATA33 mutation and infertility in men with NOA. The authors discuss that the study population was limited to men with NOA, and encouraged that the same study be done in men with oligospermia and teratozoospermia (Monsef et al. 2018).

Piwi interacting RNA pathway

A study carried out by Kamaliyan et al. (2018) investigated the PiRNAs, which are amongst the non-coding regions of RNA and male germline development. PIWI and TDRD proteins are essential for PiRNAs to function appropriately, hence they are necessary for proper spermatogenesis. The study examined the association between polymorphisms in the HIWI genes and the risk of idiopathic non-obstructive azoospermia in Iranian males. Variations may cause RNA instability. Evidently, any variants in the PiRNA pathway genes may predispose spermatogenesis defects (Kamaliyan et al. 2018).

Extrapolating from the results, it can be suggested that the mutation or deletion of genes necessary for normal development of germ cells, even without the presence of Y chromosome microdeletion may impair male fertility by triggering altered spermatogenesis, reduced sperm function, and some may even cause the offspring to be prone to inheriting the variation. Hence, it is important to identify if male infertility is caused by a gene mutation. This will help to develop treatment strategies that would prevent the offspring from having the same mutation.

$X$-ray repair cross complementing group 1 genetic polymorphism

DNA is under constant threat and damage from various sources. The X-ray Cross Complementing Group 1 (XRCC1) gene is responsible for repairing single strand breaks in the DNA. Mutations in the XRCC1 are detected by using polymerase chain reaction reaction-restriction fragment length polymorphism (Bi et al. 2013). A study by Akbas et al. examined polymorphisms within the XRCC1 gene and their effect on male fertility. A control group was compared to a group with men that suffered from idiopathic non-obstructive azoospermia. No significant differences were reported in $X R C C 1$ polymorphisms between the control and experimental group, suggesting that XRCC1 polymorphisms do not influence male fertility (Akbas et al. 2019).

Protamine (PRM) and Y-box binding protein 2 (YBX2)

Protamine (PRM) genes produce protamine, which are small arginine rich proteins and are believed to be essential for DNA stabilization and function to condense spermatid genome (Domenjoud et al. 1991). Y-box binding protein 2(YBX2) is essential in the transcription, translation, and splicing of mRNA. A study by Aydos et al. aimed to demonstrate the effects of polymorphism in such genes, and whether they can potentially affect male fertility. It was reported that $P R M 1$ polymorphism was associated with sperm DNA fragmentation, while a polymorphism in $P R M 2$ and $Y B X 2$ were not associated with male fertility (Aydos et al. 2018).

\section{Single nucleotide polymorphisms (SNPs)}

Single nucleotide polymorphisms (SNPs) are the replacement of a nucleotide at a single position within the genome, giving rise to a new allele. A SNP may occur anywhere along the genome, affecting genetic integrity. If it occurs on the sex chromosomes it may hinder the maturation of sperm, leading to infertility (Ben khelifa et al. 2011, Gurkan et al. 2013, Haji Ebrahim Zargar et al. 2015, Yousefi et al. 2015, Najafipour et al. 2016, Kamaliyan et al. 2018, Nasirshalal et al. 2020, Pashaei et al. 2020). Understanding the specifics of where the gene is mutated, and how it can lead to male infertility is vital in the treatment and management plan of the patient. 


\section{Evidence of SNPS occurrence in the MENA region}

A study conducted by Zargar et al. (2015) discussed the relationship between variation in the X-linked gene and a specific pattern of male infertility. They reported that a gene on the $\mathrm{x}$ chromosome, known as $\mathrm{H} 2 \mathrm{~B} . \mathrm{W}$, is linked to male infertility (Haji Ebrahim Zargar et al. 2015). The study discovered two SNPs (-9C>T and $368 \mathrm{~A}>\mathrm{G})$ in the $H 2 B . W$ gene in a population of infertile Iranian men.

The study showed that the -9T frequency at the -9C $>\mathrm{T}$ position was higher in the complete maturation arrest group than in the SCOS group. This suggests that the variation of allele $\mathrm{C}$ to $\mathrm{T}$ might influence the mRNA stability affecting the maturation of the spermatids. However, there was no significant association between SNP 368A $>\mathrm{G}$ and the risk of infertility in the Iranian male population (Haji Ebrahim Zargar et al. 2015).

Another study analysed the whole blood samples of 180 idiopathic infertile males and 120 fertile controls to investigate the association between the occurrence of gene polymorphism $(-656 \mathrm{~T}>\mathrm{G}$ and $1349>\mathrm{G}$ variants in the ApE1 promoter and coding region) and the susceptibility to idiopathic male infertility (Yousefi et al. 2015). ApE1 is responsible for maintaining genomic integrity, a polymorphism in this gene might lead to infertility as it may cause damage to the DNA leading to reproductive disorders. The study revealed that $-656 \mathrm{~T}>\mathrm{G}$ polymorphism is related to infertility, while a variation in the $1349 \mathrm{~T}>\mathrm{G}$ region was unrelated to idiopathic male infertility (Yousefi et al. 2015).

\section{Chromosomal disorders}

The implication of chromosomal disorders on male infertility including numerical, structural, replacement, inversion, insertion and translocational chromosomal abnormalities have been explored and documented (Balkan et al. 2008, Akgul et al. 2009, Alhalabi et al. 2013), especially for the numerical and structural chromosome disorders (Balkan et al. 2008, Alhalabi et al. 2013).

\section{Evidence of chromosomal disorders in the MENA region}

Coming to the MENA region, Mehdi et al. (2012) reported a significantly increased frequency of chromosome 1818XY, $X X$, and YY disomies in the spermatozoa of men with severe teratozoospermia from Tunisia (Mehdi et al. 2012). The rate of total diploidy was also increased. Another study from Turkey showed that out of 179 infertile men that were evaluated, a total of 21 cases (11.74\%) showed chromosomal alteration. This include $13(7.26 \%)$ that were $47, \mathrm{XXY}$; three $(1.68 \%)$ were pericentric inversion of chromosome 9 , one ( $0.56 \%$ ) 46,XY/45, XO, one (0.56\%) 46,XY/47,XXY/48,XXXY, one $(0.56 \%)$ 46,XY,t(X;1), one (0.56\%) 46,XY/46,XY,del(Y)(q11.2), and one (0.56\%) 46,XX (Akgul et al. 2009). The occurrence of diploidy originating from either meiotic maturation or by a compromised testicular environment may impair male fertility. A case report by Balasar et al. demonstrates that not all chromosomal mutations will result in variation in the AZF and SRY regions (Balasar et al. 2017), which demonstrates the importance of understanding the differences in variation to properly treat infertility.

\section{Mitochondrial mutation}

The mitochondrion is a double-membrane organelle that generates about $90 \%$ of cell energy in the form of adenosine triphosphate by oxidative phosphorylation reaction in mammalian cells. Mitochondria play a crucial role in a series of signal pathways, including tricarboxylic acid cycle, the $\beta$-oxidation of fatty acids, regulation of intrinsic apoptosis, and participating in the cell cycle (Arakaki et al. 2006, Finkel and Hwang 2009, Yan et al. 2019). In contrast to the other organelles in a mammalian cell, mitochondria have DNA, known as mitochondrial DNA (mtDNA), which encodes a series of crucial proteins for mitochondrial respiration. The mtDNA is particularly susceptible to certain stress-induced damages due to a lack of histones in the structure and effective repair mechanisms (Kujoth et al. 2005) mtDNA mutation caused by stress-induced damage is highly associated with various human diseases, including male infertility (Venkatesh et al. 2009).

\section{Evidence of mitochondria mutation in the MENA region}

Abnormal sperm function has been identified as one of the leading causes of male infertility. Defective sperm motility has been recognized as one of the primary causes of abnormal sperm function. Gashti et al. (2013) reported that variations in mtDNA in ATP generating genes may cause infertility, as mtDNA deletion was observed in $81.66 \%$ of infertile men with varicocele. This means that varicocele may induce mtDNA deletion in spermatozoa and cause infertility (Gashti et al. 2014). Many factors can contribute to mtDNA damage, such as infection, lifestyle, diet, and the environment. These factors promote the production of ROS, at a high level of oxidative damage, spermatozoa may be damaged, promoting infertility. Sperm plasma membranes are rich in poly-unsaturated fatty acids, which makes the membrane prone to oxidative damage. Nasrin also reported that ROS in testicular tissue and semen may lead to mtDNA microdeletions, which affects the electron transport chain, which is consequently a direct cause of male infertility. 


\section{Clinical implications}

In vitro fertilization (IVF) and Intracytoplasmic Sperm Injection (ICSI) have allowed couples with fertility problems to achieve success. The success of these procedures varies from couple to couple, due to the fact that different couples present with diverse causes of male infertility. A study by Ocak et al. explored the causes of reproductive failure in a cohort of 500 patients. They found that the causes of infertility ranged from no chromosomal variations to Y-chromosomal variation. Thus, demonstrating the importance of genetic testing before commencing assisted reproductive techniques (ART) (Ocak et al. 2014). With that being said, most patients are still willing to attempt such procedures, as these procedures present as a last hope option.

Y chromosome microdeletion is one of the most common causes of male infertility; many males who suffer from Y chromosome microdeletion undergo IVF and ICSI. Screening for Y chromosome microdeletion has become a standard practice before partaking in either IVF or ICSI, as they may offer a prognostic value, predicting the potential success for ART (Sadeghi-Nejad and Farrokhi 2007). Knowing the type of Y chromosome microdeletion may help offer some prognostic value, as not all types of microdeletions yield the same results with ART. It has been demonstrated that sperm retrieval through testicular sperm extraction was possible in patients with AZFC microdeletion but not possible in AZFA and AZFB (Krausz et al. 2000, Hopps et al. 2003). A more recent study by Abur et al. also demonstrated that ART was possible with AZFC deletion (Abur et al. 2019), marking the importance of differentiating between types of Y-chromosome microdeletion before commencing ART. Other chromosomal abnormalities may affect the success rate of ART; such an example would be $46 \mathrm{XX}$ chromosomal abnormalities. Akar et al. reported that other than the clinical and laboratory findings of $46 \mathrm{XX}$ chromosomal translocation, patients with such a condition may have to resort to a sperm donor as sperm retrieval is not a viable option in such a patient population (Akar et al. 2020). Furthermore, this patient population should opt for testosterone replacement therapy to be protected against the negative effects of testosterone deficiency (Akinsal et al. 2017).

Additionally, high levels of aneuploidy are positively associated with an increased level of male factor infertility (Schulte et al. 2010). As such, sperm with aneuploidy is associated with a higher rate of failure with ART (Harton and Tempest 2012). Sperm relies on energy from the mitochondria for its motility, therefore, any variation in mtDNA leads to altered motility, negatively impacting fertility outcomes. A proposed solution for such infertility is ICSI. Studies now show that although mitochondrial DNA variation has a negative impact on ICSI outcomes, it is still possible (Al Smadi et al. 2021). Sperm DNA integrity is one of the vital prognostic factors of male fertility. Anything that compromises sperm DNA can lead to infertile outcomes. The findings on IVF outcomes in patients with abnormal sperm DNA have been conflicting. Some studies state that variation in the DNA of sperm have no effect on fertility outcomes (Collins et al. 2008), while others state otherwise (Simon et al. 2017). The controversy may be due to the diversity methodological approaches. Hence, it is suggested that a standardized protocol be developed.

Upon achieving success with ART, the main concern shifts to the possible vertical transmission to the offspring. Reports have shown that microdeletions have the capability of transmitting to the offspring by ICSI (Jiang et al. 1999, Zhu et al. 2010). Unfortunately, vertical transmission of Y chromosome microdeletion have been reported to cause infertility in offspring (Kim et al. 2003, Dai et al. 2012). Studies have also shown that males with aneuploidy have a higher chance of giving birth to children with aneuploidy which can translate to a variety of health conditions (Harton and Tempest 2012). This dilemma requires the design of further prospective clinical cohort studies that will assess whether the deleted regions on the $\mathrm{Y}$ chromosome are amplified and whether they can cause any significant new health consequences. Investigations on the possible transmission of damaged DNA should also be developed.

\section{Conclusion}

In comparison to the data available on the global investigation of infertility, particularly male infertility, findings about this subject in the MENA region is lacking. This may be due to the poorly funded niche-specific research, or social stigmatization. Accessibility to the few studies has revealed that the prevalence of demographic male infertility in the MENA region is on the increase, which makes the investigation of the causes of male infertility important.

In addition to semen analysis derived diagnosis, studies have indicated the role of genetic abnormalities as part of the cause of male infertility. Findings from the current study showed that the prevalent genetic aberration leading to male infertility in the MENA region include Y chromosome microdeletion, the occurrence of gene polymorphism, mitochondrial microdeletion and other genetic deletions or mutations.

The study of male infertility in the MENA region should encompass the investigation of various genetic variations. Diverse clinical genetic tests should also be made available for the proper diagnosis of male infertility. This would furthermore help researchers and clinicians to develop informed treatment strategies. Additionally, before providing 
couples with ART options, a thorough screening should be performed, and the scope of interest of reproductive medicine physicians should as well include understanding the root cause of infertility rather than just establishing pregnancy.

\section{Data availability}

No data is associated with this article.

\section{References}

Abur U, Gunes S, AscI R, et al.: Chromosomal and Y-chromosome microdeletion analysis in 1,300 infertile males and the fertility outcome of patients with AZFc microdeletions. Andrologia. 2019; 51: e13402.

PubMed Abstract | Publisher Full Text

Akar OS, Gunes S, Abur U, et al:: Multiscale analysis of SRY-positive 46,XX testicular disorder of sex development: Presentation of nine cases. Andrologia. 2020; 52(11): 1-10.

Publisher Full Text

Akbari A, Pipitone GB, Anvar Z, et al.: ADCY10 frameshift variant leading to severe recessive asthenozoospermia and segregating with absorptive hypercalciuria. Hum. Reprod. 2019; 34(6): 1155-1164 PubMed Abstract | Publisher Full Text

Akbarzadeh Khiavi M, Jalili A, Safary A, et al.: Karyotypic abnormalities and molecular analysis of $\mathrm{Y}$ chromosome microdeletion in Iranian Azeri Turkish population infertile men. Syst. Biol. Reprod. Med. 2020; 66(2): 140-146

PubMed Abstract | Publisher Full Text

Akbas H, Balkan M, Binici M, et al: The Possible Role of XRCC1 Gene Polymorphisms with Idiopathic Non-obstructive Azoospermia in Southeast Turkey. Urol. J. 2019; 16(4): 380-385.

PubMed Abstract | Publisher Full Text

Akgul M, Ozkinay F, Ercal D, et al.: Cytogenetic abnormalities in 179 cases with male infertility in Western Region of Turkey: Report and review. J. Assist. Reprod. Genet. 2009; 26(2-3): 119-122.

PubMed Abstract | Publisher Full Text

Akinsal EC, Baydilli N, Demirtas A, et al.: Ten cases with 46,XX testicular disorder of sex development: single center experience. International Brazilian Journal of Urology: Official Journal of the Brazilian Society of Urology. 2017; 43(4): 770-775.

PubMed Abstract | Publisher Full Text | Free Full Text

Al-Agha AE, Ahmed IA, Nuebel E, et al.: Primary ovarian insufficiency and azoospermia in carriers of a homozygous PSMC3IP stop gain

mutation. J. Clin. Endocrinol. Metab. 2018; 103(2): 555-563.

PubMed Abstract | Publisher Full Text

Al-Janabi AM, Rahim AI, Faris SA, et al.: Prevalence of $\mathrm{Y}$ chromosome microdeletion in azoospermic infertile males of Iraqi population.

J. Genet. 2020; 99(1): 1-5.

Publisher Full Tex

Alazami AM, Alshammari MJ, Baig M, et al.: NPHP4 mutation is linked to cerebello-oculo-renal syndrome and male infertility. Clin. Genet. 2014; 85(4): 371-375.

PubMed Abstract | Publisher Full Text

Alhalabi M, Kenj M, Monem F, et al.: High prevalence of genetic abnormalities in Middle Eastern patients with idiopathic non obstructive azoospermia. J. Assist. Reprod. Genet. 2013; 30(6): 799-805. PubMed Abstract | Publisher Full Text

Alimohammadi F, Ebrahimi Nasab M, Rafaee A, et al.: Deletion of dpy-19 like 2 (DPY19L2) gene is associated with total but not partial globozoospermia. Reprod. Fertil. Dev. 2020; 32: 727.

Publisher Full Text

Arakaki N, Nishihama T, Owaki H, et al.: Dynamics of mitochondria during the cell cycle. Biol. Pharm. Bull. 2006; 29(9): 1962-1965.

Publisher Full Tex

Asadpor U, Totonchi M, Sabbaghian M, et al.: Ubiquitin-specific protease (USP26) gene alterations associated with male infertility and recurrent pregnancy loss (RPL) in Iranian infertile patients. J. Assist. Reprod. Genet. 2013; 30(7): 923-931.

PubMed Abstract | Publisher Full Text

Askari M, Karamzadeh R, Ansari-Pour N, et al.: Identification of a missense variant in CLDN2 in obstructive azoospermia. J. Hum. Genet. 2019; 64(10): 1023-1032.

PubMed Abstract | Publisher Full Text

Askari M, Kordi-Tamandani DM, Almadani N, et al.: Identification of a homozygous GFPT2 variant in a family with asthenozoospermia. Gene.
2019; 699: 16-23.

PubMed Abstract | Publisher Full Text

Avenarius MR, Hildebrand MS, Zhang Y, et al.: Human Male Infertility Caused by Mutations in the CATSPER1 Channel Protein. Am. J. Hum. Genet. 2009; 84(4): 505-510.

PubMed Abstract | Publisher Full Text

Aydos OSE, Hekmatshoar Y, Altlnok B, et al.: Genetic Polymorphisms in PRM1, PRM2, and YBX2 Genes are Associated with Male Factor Infertility.2018; 22(1): 55-61.

Publisher Full Text | Reference Source

Balasar Ö, Zamani AG, Balasar M, et al.: Male infertility associated with de novo pericentric inversion of chromosome 1. Turk.J. Urol. 2017; 43(4): 560-562.

PubMed Abstract | Publisher Full Text

Balkan M, Tekes S, Gedik A: Cytogenetic and Y chromosome microdeletion screening studies in infertile males with

Oligozoospermia and Azoospermia in Southeast Turkey. J. Assist.

Reprod. Genet. 2008; 25(11-12): 559-565.

PubMed Abstract | Publisher Full Text

Beyaz CC, Gunes S, Onem K, et al.: Partial Deletions of Y-Chromosome in Infertile Men with Non-obstructive Azoospermia and

Oligoasthenoteratozoospermia in a Turkish Population. In Vivo. 2017; 31(3): 365-371.

PubMed Abstract | Publisher Full Text

Bi J, Zhong C, Li K, et al.: Association study of single nucleotide polymorphisms in XRCC1 gene with risk of hepatocellular carcinoma in Chinese Han population. Biomed. Res. Int. 2013; 2013: 1-6.

PubMed Abstract | Publisher Full Text

Vander Borght $M$, Wyns C: Fertility and infertility: Definition and epidemiology. Clin. Biochem. 2018; 62: 2-10.

PubMed Abstract | Publisher Full Text

Ceylan GG, Ceylan C, Elyas H: Genetic anomalies in patients with severe oligozoospermia and azoospermia in eastern Turkey: A prospective study. Genet. Mol. Res. 2009; 8(3): 915-922.

PubMed Abstract | Publisher Full Text

Chen CP: Chromosomal abnormalities associated with omphalocele.

Taiwan. J. Obstet. Gynecol. 2007; 46: 1-8.

Publisher Full Text

Colaco S, Modi D: Genetics of the human Y chromosome and its association with male infertility. Reprod. Biol. Endocrinol. 2018; 16: 14 PubMed Abstract | Publisher Full Text

Collins JA, Barnhart KT, Schlegel PN: Do sperm DNA integrity tests predict pregnancy with in vitro fertilization?. Fertil. Steril. 2008; 89(4): 823-831.

PubMed Abstract | Publisher Full Text

Dai RL, Sun LK, Yang X, et al.: Expansion and de novo occurrence of $Y$ chromosome microdeletions occurring via natural vertical transmission in Northeastern China. J. Int. Med. Res. 2012; 40(3): 1182-1191.

Publisher Full Text

Dhanoa JK, Mukhopadhyay CS, Arora JS: Y-chromosomal genes affecting male fertility: A review. Veterinary World. 2016; 9(7): 783-791.

PubMed Abstract | Publisher Full Text

Domenjoud L, Kremling $\mathrm{H}$, Burfeind $\mathrm{P}$, et al.: On the expression of protamine genes in the testis of man and other mammals. Andrologia. 1991; 23(5): 333-337.

PubMed Abstract | Publisher Full Text

Eldib A, Tashani O: Infertility in the Middle East and North Africa

Region: A systematic review with meta-Analysis of prevalence

surveys. Libyan Journal of Medical Sciences. 2018; 2(2): 37.

Publisher Full Text

Elsawi MM, Pryor JP, Klufio G, et al.: Genital tract function in men with Noonan syndrome. J. Med. Genet. 1994; 31(6): 468-470.

PubMed Abstract | Publisher Full Text | Free Full Text 
Etem EO, Erol D, Huseyin Y, et al.: Mediterranean fever gene mutation analysis in infertile Turkish males. Genet. Mol. Res. 2010; 9(2): 611-619.

PubMed Abstract | Publisher Full Text

Ferlin A, Arredi B, Foresta C: Genetic causes of male infertility. Reprod Toxicol. 2006; 22(2): 133-141.

Publisher Full Text

Finkel T, Hwang PM: The Krebs cycle meets the cell cycle: Mitochondria and the G1-S transition. Proc. Natl. Acad. Sci. U. S. A. 2009; 106

11825-11826.

PubMed Abstract | Publisher Full Text

Foresta C, Ferlin A, Moro E: Deletion and expression analysis of AZFa genes on the human $Y$ chromosome revealed a major role for DBY in male infertility. Hum. Mol. Genet. 2000; 9(8): 1161-1169.

PubMed Abstract | Publisher Full Text

Gashti NG, Salehi Z, Madani AH, et al.: 4977-bp mitochondrial DNA deletion in infertile patients with varicocele. Andrologia. 2014; 46(3): 258-262.

PubMed Abstract | Publisher Full Text

Ghorbian S, Saliminejad K, Sadeghi MR, et al.: The association between $Y$ chromosome microdeletion and recurrent pregnancy loss. Iran Red. Crescent Med. J. 2012; 14(6): 358-362.

PubMed Abstract

Gurkan H, Aydin F, Kadioglu A, et al.: Investigation of mutations in the synaptonemal complex protein 3 (SYCP3) gene among azoospermic infertile male patients in the Turkish population. Andrologia. 2013;

45(2): 92-100.

PubMed Abstract | Publisher Full Text

Haji Ebrahim Zargar H, Mohseni Meybodi A, Sabbaghian M, et al.: Association of two polymorphisms in H2B.W gene with azoospermia and severe oligozoospermia in an Iranian population. Int. J. Fertil. Steril. 2015; 9(2): 205-214.

PubMed Abstract

Harton GL, Tempest HG: Chromosomal disorders and male infertility. Asian J. Androl. 2012; 14: 32-39.

PubMed Abstract | Publisher Full Text

Hellani A, Al-Hassan S, Al-Duraihim A, et al.: Y chromosome microdeletions: Are they implicated in teratozoospermia?. Hum. Reprod. 2005; 20(12): 3505-3509.

PubMed Abstract | Publisher Full Text

Hojati Z, Soleimanpour E, Javadirad SM, et al.: Identification of two novel mutations in KDM3A regulatory gene in iranian infertile males. Iran. Biomed. J. 2019; 23(3): 220-227.

PubMed Abstract | Publisher Full Text

Hopps CV, Mielnik A, Goldstein M, et al.: Detection of sperm in men with $Y$ chromosome microdeletions of the AZFa, AZFb, and AZFc regions.

Hum. Reprod. 2003; 18(8): 1660-1665.

PubMed Abstract | Publisher Full Text

Ikechebelu JI, Adinma JIB, Orie EF, et al.: High prevalence of male infertility in southeastern Nigeria. J. Obstet. Gynaecol. 2003; 23(6):

$657-659$.

PubMed Abstract | Publisher Full Text

Jamshidi J, Pouresmaeili F, Darvish H, et al.: FABP9 mutations are not detected in cases of infertility due to sperm morphological defects in Iranian Men. Int J. Fertil. Steril. 2014; 7(4): 275-280.

PubMed Abstract

Jiang MC, Lien YR, Chen SU, et al.: Transmission of de novo mutations of the deleted in azoospermia genes from a severely oligozoospermic male to a son via intracytoplasmic sperm injection. Fertil. Steril. 1999; 71(6): 1029-1032.

Publisher Full Text

Kamaliyan Z, Pouriamanesh S, Soosanabadi M, et al.: Investigation of piwi-interacting RNA pathway genes role in idiopathic non-

obstructive azoospermia. Sci. Rep. 2018; 8(1): 142 .

PubMed Abstract | Publisher Full Text

Karabulut S, Keskin I, Kutlu P, et al.: Male infertility, azoozpermia and cryptozoospermia incidence among three infertility clinics in Turkey. Turk. J. Urol. 2018; 44(2): 109-113.

Publisher Full Text

Ben Khelifa M, Zouari R, Harbuz R, et al.: A new AURKC mutation causing macrozoospermia: Implications for human spermatogenesis and clinical diagnosis. Mol. Hum. Reprod. 2011; 17(12): 762-768.

PubMed Abstract | Publisher Full Text

Kim HA, Lee SH, Cho SW, et al.: Vertical transmission, de novo, and expansion of $Y$ chromosome microdeletion in male fetuses pregnant after intracytoplasmic sperm injection (ICSI). Fertil. Steril. 2003; 80: 113

Publisher Full Text

Koc G, Ozdemir AA, Girgin G, et al.: Male infertility in Sertoli cell-only syndrome: An investigation of autosomal gene defects. Int. J. Urol. 2019; 26(2): 292-298.

PubMed Abstract | Publisher Full Text
Kovac JR, Pastuszak AW, Lamb DJ: The use of genomics, proteomics and metabolomics in identifying biomarkers of male infertility. Bone. 2014; 23(1): 1-7.

Krausz C, Quintana-Murci L, McElreavey K: Prognostic value of Y deletion analysis: What it the clinical prognostic value of $Y$ chromosome microdeletion analysis?. Hum. Reprod. 2000; 15: 1431-1434.

PubMed Abstract | Publisher Full Text

Kujoth CC, Hiona A, Pugh TD, et al.: Medicine: Mitochondrial DNA mutations, oxidative stress, and apoptosis in mammalian aging. Science. 2005; 309(5733): 481-484.

Publisher Full Text

Kuroda S, Usui K, Sanjo H, et al.: Genetic disorders and male infertility. Reprod. Med. Biol. 2020; 19: 314-322.

PubMed Abstract | Publisher Full Text

Madgar I, Green L, Kent-First M, et al.: Genotyping of Israeli infertile men with idiopathic oligozoospermia. Clin. Genet. 2002; 62(3): 203-207. Publisher Full Text

Mascarenhas MN, Flaxman SR, Boerma T, et al: National, Regional, and Global Trends in Infertility Prevalence Since 1990: A Systematic Analysis of $\mathbf{2 7 7}$ Health Surveys. PLoS Med. 2012; 9(12): 1-12.

Publisher Full Text

Mehdi $\mathrm{M}$, Gmidène $\mathrm{A}$, Brahem $\mathrm{S}$, et al.: Aneuploidy rate in spermatozoa

of selected men with severe teratozoospermia. Andrologia. 2012; 44

(SUPPL 1): 139-143.

PubMed Abstract | Publisher Full Text

Mirfakhraie R, Mirzajani F, Kalantar SM, et al.: High prevalence of AZFb

microdeletion in Iranian patients with idiopathic non-obstructive

azoospermia. Indian J. Med. Res. 2010; 132(9): 265-270.

Mohammad-Hasani A, Hosseinzadeh Colagar A, Fallah A: Association of

the human aryl hydrocarbon receptor repressor (AhRR)-c.565C $>G$

transversion with male infertility: A case-control study from Iran.

J. Cell. Biochem. 2019; 120(6): 8999-9005.

PubMed Abstract | Publisher Full Text

Monsef L, Borjian Boroujeni P, Totonchi M, et al.: Gene alterations and expression spectrum of SPATA33 in nonobstructive azoospermic Iranian men. Mol. Reprod. Dev. 2018; 85(10): 760-767.

PubMed Abstract | Publisher Full Text

Najafipour R, Rashvand Z, Alizadeh A, et al.: Association of G/T (rs222859)

polymorphism in Exon 1 of YBX2 gene with azoospermia, among

Iranian infertile males. Andrologia. 2016; 48(9): 1044-1048.

PubMed Abstract | Publisher Full Text

Nasirshalal M, Tahmasebi-Birgani M, Dadfar M, et al.: Identification of the PRM1 gene mutations in oligoasthenoteratozoospermic men.

Andrologia. 2020; 52(11): e13872.

PubMed Abstract | Publisher Full Text

Ocak Z, Üyetürk U, Dinçer MM: Clinical and prognostic importance of chromosomal abnormalities, Y chromosome microdeletions, and CFTR gene mutations in individuals with azoospermia or severe oligospermia. Turk. J. Med. Sci. 2014; 44(2): 347-351.

Publisher Full Tex

Okada $\mathrm{H}$, Fujioka $\mathrm{H}$, Tatsumi $\mathrm{N}$, et al.: Klinefelter's syndrome in the male infertility clinic. Hum. Reprod. 1999; 14(4): 946-952.

Publisher Full Text

Organization, W.H. (WHO): International Classification of Diseases. WHO; 2018.

Pashaei M, Rahimi Bidgoli MM, Zare-Abdollahi D, et al.: The second mutation of SYCE1 gene associated with autosomal recessive nonobstructive azoospermia. J. Assist. Reprod. Genet. 2020; 37(2): 451-458.

PubMed Abstract | Publisher Full Text

Poongothai J, Gopenath TS, Manonayaki S, et al.: Genetics of human male infertility. Singap. Med. J. 2009; 50(4): 336-347.

PubMed Abstract

Punab M, Poolamets $O$, Paju P, et al: Causes of male infertility: A 9-year prospective monocentre study on 1737 patients with reduced total sperm counts. Hum. Reprod. 2017; 32(1): 18-31.

PubMed Abstract | Publisher Full Text

Sadeghi-Nejad H, Farrokhi F: Genetics of azoospermia: current knowledge, clinical implications, and future directions. Part II: $Y$ chromosome microdeletions. Urol. J. 2007; 4: 192-206.

PubMed Abstract

Saliminejad K, Sadeghi MR, Kamali K, et al.: Discrepancy in the frequency of $y$ chromosome microdeletions among iranian infertile men with azoospermia and severe oligozoospermia. Genet. Test. Mol. Biomarkers. 2012; 16(8): 931-934.

PubMed Abstract | Publisher Full Text

Schulte RT, Ohl DA, Sigman M, et al.: Sperm DNA damage in male infertility: Etiologies, assays, and outcomes. J. Assist. Reprod. Genet 2010; 27: 3-12.

PubMed Abstract | Publisher Full Text

Shahid M, Dhillon VS, Khalil HS, et al.: A SRY-HMG box frame shift mutation inherited from a mosaic father with a mild form of 
testicular dysgenesis syndrome in Turner syndrome patient. BMCMed. Genet. 2010; 11(1)

PubMed Abstract | Publisher Full Text

Shaveisi-Zadeh F, Alibakhshi R, Asgari R, et al.: TTY2 genes deletions as genetic risk factor of male infertility. Cell. Mol. Biol. 2017; 63(2):

57-61.

PubMed Abstract | Publisher Full Text

Simon L, Zini A, Dyachenko A, et al.: A systematic review and metaanalysis to determine the effect of sperm DNA damage on in vitro fertilization and intracytoplasmic sperm injection outcome. Asian J. Androl. 2017; 0: 0

Publisher Full Text

Al Smadi MA, Hammadeh ME, Solomayer E, et al.: Impact of Mitochondrial Genetic Variants in ND1, ND2, ND5, and ND6 Genes on Sperm Motility and Intracytoplasmic Sperm Injection (ICSI)

Outcomes. Reprod. Sci. 2021; 28(5): 1540-1555.

PubMed Abstract | Publisher Full Text

Sokol RZ, Shapiro BJ: Infertility in men with cystic fibrosis. Curr. Opin. Pulm. Med. 2001; 7: 421-426.

Publisher Full Text

Stahl PJ, Mielnik AN, Barbieri CE, et al.: Deletion or underexpression of the Y-chromosome genes CDY2 and HSFY is associated with

maturation arrest in American men with nonobstructive

azoospermia. Asian J. Androl. 2012; 14(5): 676-682.

PubMed Abstract | Publisher Full Text

Stanton PG, Sluka P, Foo CFH, et al.: Proteomic changes in rat spermatogenesis in response to in vivo androgen manipulation;

Impact on meiotic cells. PLoS One. 2012; 7(7): e41718.

PubMed Abstract | Publisher Full Text
Sun H, Gong TT, Jiang YT, et al.: Global, Regional, and National Prevalence and Disability-Adjusted Life-Years for Infertility in 195 Countries and Territories, 1990-2017: Results from a Global Burden of Disease Study, 2017. Aging. 2019; 11(23): 10952-10991. PubMed Abstract | Publisher Full Text

Totonchi M, Mohseni Meybodi A, Borjian Boroujeni P, et al.: Clinical data for 185 infertile Iranian men with Y-chromosome microdeletion.

J. Assist. Reprod. Genet. 2012; 29(8): 847-853.

Publisher Full Text

Venkatesh S, Deecaraman M, Kumar R, et al.: Role of reactive oxygen species in the pathogenesis of mitochondrial DNA (mtDNA)

mutations in male infertility. Indian J. Med. Res. 2009; 129(2): 127-137. PubMed Abstract

Vicdan A, Vicdan K, Günalp S, et al.: Genetic aspects of human male infertility: The frequency of chromosomal abnormalities and $Y$ chromosome microdeletions in severe male factor infertility. Eur. J. Obstet. Gynecol. Reprod. Biol. 2004; 117(1): 49-54.

PubMed Abstract | Publisher Full Text

Yan C, Duanmu X, Zeng L, et al.: Mitochondrial DNA: Distribution,

Mutations, and Elimination. Cell. 2019; 8(379): 1-15.

Publisher Full Text

Yousefi M, Salehi Z, Mashayekhi F, et al.: The association of ApE1 -656T>G and 1349T>G polymorphisms and idiopathic male infertility risk. Int Urol. Nephrol. 2015; 47(6): 921-926.

PubMed Abstract | Publisher Full Tex

Zhu XB, Liu YL, Zhang W, et al.: Vertical transmission of the Yq AZFc microdeletion from father to son over two or three generations in infertile Han Chinese families. Asian J. Androl. 2010; 12(2): 240-246.

PubMed Abstract | Publisher Full Text 


\section{Open Peer Review}

\section{Current Peer Review Status: ? ?}

\section{Version 1}

Reviewer Report 05 May 2022

https://doi.org/10.5256/f1000research.117957.r135107

(C) 2022 Achermann A. This is an open access peer review report distributed under the terms of the Creative Commons Attribution License, which permits unrestricted use, distribution, and reproduction in any medium, provided the original work is properly cited.

\section{Arnold Peter Paul Achermann}

Department of Surgery, Division of Urology, Faculty of Medical Sciences, University of Campinas (UNICAMP), Campinas, Brazil

In this paper, the authors summarize the current evidence concerning the importance of the genetic causes of male infertility in the Middle East and North Africa (MENA) region.

The Abstract offers a clear, synthetic, and complete overview of the messages emerging from the Review. However, the authors should update information about the percentage of idiopathic cases in male infertility.

Although difficult to read of the complex theme, the Review is written linearly and deals with everything related to genetic causes of male infertility in the MENA region in separate chapters.

I suggest minor corrections:

"The AZF region is made up of multiple genomic loci, including AZFa, AZFb, AZFc, AZFd. These regions are believed to be responsible for spermatogenesis" The authors should add that deletions can be isolated or combined in each AZF region.

"Albeit that the presence of DAZ deletions in both fertile and infertile men question its importance, the former although fertile have lower sperm counts and reduced sperm motility." Confused, clarify.

Is the KDM3A gene an autosome dominant or recessive gene?

The paragraph about (SPATA33) is about the Iranian population studied. However, the authors did not expose it.

"Nasrin also reported that ROS in testicular tissue and semen may lead to mtDNA microdeletions, which affects the electron transport chain, which is consequently a direct cause of male infertility." - there is no reference for this information. 
"It has been demonstrated that sperm retrieval through testicular sperm extraction was possible in patients with AZFC microdeletion but not possible in AZFA and AZFB (Krausz et al. 2000, Hopps et al. 2003). A more recent study by Abur et al. also demonstrated that AR was possible with AZFC deletion (Abur et al. 2019), marking the importance of differentiating between types of Y-chromosome microdeletion before commencing ART." please correct the expressions. It should be AZFa, AZFb, AZFc.

Is the topic of the review discussed comprehensively in the context of the current literature?

Yes

Are all factual statements correct and adequately supported by citations?

Partly

Is the review written in accessible language?

Partly

Are the conclusions drawn appropriate in the context of the current research literature? Yes

Competing Interests: No competing interests were disclosed.

Reviewer Expertise: Male infertility, micro-TESE, azoospermia, Non-obstructive azoospermia, hypogonadism

I confirm that I have read this submission and believe that I have an appropriate level of expertise to confirm that it is of an acceptable scientific standard, however I have significant reservations, as outlined above.

Author Response 29 May 2022

Temidayo S Omolaoye

Comment:

In this paper, the authors summarize the current evidence concerning the importance of the genetic causes of male infertility in the Middle East and North Africa (MENA) region. The Abstract offers a clear, synthetic, and complete overview of the messages emerging from the Review. However, the authors should update information about the percentage of idiopathic cases in male infertility.

Although difficult to read of the complex theme, the Review is written linearly and deals with everything related to genetic causes of male infertility in the MENA region in separate chapters.

Response:

The authors would like to thank the reviewer for the positive remark and for taking the time and effort to review this work, thereby adding to the scientific merit of this study.

Suggestions made by the reviewer have been addressed appropriately. 
The prevalence of idiopathic cases in male infertility have been updated both in the abstract and main text.

\section{Comment:}

I suggest minor corrections:

"The AZF region is made up of multiple genomic loci, including AZFa, AZFb, AZFc, AZFd. These regions are believed to be responsible for spermatogenesis" The authors should add that deletions can be isolated or combined in each AZF region.

\section{Response:}

The suggested comment has been added in the text. Line 139-140

\section{Comment:}

"Albeit that the presence of DAZ deletions in both fertile and infertile men question its importance, the former although fertile have lower sperm counts and reduced sperm motility." Confused, clarify.

\section{Response:}

The below sentence has been inserted in the text. Line 163-167

"Although, the presence of DAZ gene copies (DAZ2 or DAZ4) deletions was observed in some fertile men, the deletion of both copies were more frequent in infertile men with oligospermia (Ghorbel et al. 2014). This indicate that the concurrent deletion of DAZ2 and DAZ4 gene copies is associated with male infertility, and that oligospermia seems to be promoted by deleting DAZ4 copy (Ghorbel et al. 2014, Al-Janabi et al. 2020)."

\section{Comment:}

Is the KDM3A gene an autosome dominant or recessive gene?

\section{Response:}

According to the available literature, the dominant or recessive status of KDM3A gene is not yet clarified. However, this gene encodes a zinc finger protein that contains a jumonji domain and plays a role in hormone-dependent transcriptional activation by participating in recruitment to androgen-receptor target genes, which result in H3 'Lys-9' demethylation and transcriptional activation. Additionally, it is involved in spermatogenesis by regulating expression of target genes such as PRM1 and TNP1 which are required for packaging and condensation of sperm chromatin. It functions suggest that it may be a dominant gene.

\section{Comment:}

The paragraph about (SPATA33) is about the Iranian population studied. However, the authors did not expose it.

\section{Response:}

Findings from the study on SPATA33 has been given in details in the text.

\section{Comment:}

"Nasrin also reported that ROS in testicular tissue and semen may lead to mtDNA microdeletions, which affects the electron transport chain, which is consequently a direct cause of male infertility." - there is no reference for this information.

\section{Response:}

The reference has been inserted. 


\section{Comment:}

"It has been demonstrated that sperm retrieval through testicular sperm extraction was possible in patients with AZFC microdeletion but not possible in AZFA and AZFB (Krausz et al. 2000, Hopps et al. 2003). A more recent study by Abur et al. also demonstrated that AR was possible with AZFC deletion (Abur et al. 2019), marking the importance of differentiating between types of Y-chromosome microdeletion before commencing ART." please correct the expressions. It should be AZFa, AZFb, AZFc.

Response:

Changes have been affected in the entire manuscript.

Competing Interests: Authors declare no conflict of interest.

Reviewer Report 30 March 2022

https://doi.org/10.5256/f1000research.117957.r126419

(C) 2022 Piasecka M. This is an open access peer review report distributed under the terms of the Creative Commons Attribution License, which permits unrestricted use, distribution, and reproduction in any medium, provided the original work is properly cited.

\section{Małgorzata Piasecka}

Department of Histology and Developmental Biology, Faculty of Health Science, Pomeranian Medical University, Szczecin, Poland

The manuscript presented to me for review concerns the genetic causes of male infertility in the Middle East and North Africa (MENA) region. The topic discussed is important and still relevant due to its clinical significance and implications. Based on a literature review (different electronic databases were searched), the authors showed that genetic aberrations ( $Y$ chromosome microdeletion, deletion or gene mutation, gene polymorphism or copy number variation, chromosomal disorders, mitochondrial mutation) are a common cause of male infertility in the MENA region. The obtained research results are comprehensively presented in Table 1 and described in the text. Taking into account the obtained data, the authors rightly suggest that genetic tests should be part of the diagnosis of male infertility. Undoubtedly, such diagnostics will allow for proper therapeutic management, especially in the case of using ART. Generally, the text is written correctly in terms of its content. However, the manuscript requires revision prior to indexing.

The most important remarks are listed below:

Abstract: "...30\% of these cases remain idiopathic." This data should be updated. Idiopathic infertility accounts for 30-50\% of male infertility (Agarwal et al., 2019,2021).

There is no information in the Introduction about idiopathic failure.

“Y chromone (?) microdeletion"; “...P or Q arm of..." should be p arm or q arm 
The content on the molecular structure of the $Y$ chromosome should also be presented in the form of a diagram (structure of the $Y$ chromosome with regions and genes marked).

The caption under figure 2 should be corrected: "...the genetic alteration the genetic alteration."

Information on ROS is contained in two sections: "Evidence of genetic mutations in the MENA region" and "Evidence of mitochondria mutation in the MENA region". I suggest that they be written exhaustively only in the section: "Evidence of mitochondria mutation in the MENA region". They should be expanded and superseded with the latest literature. The text includes many mental abbreviations.

Section: "CATSPER channel protein". "Avenarius et al. (2009) carried out a study to report the relationship between variation in the CATSPER1 channel and infertility amongst (???) Iranian men. The study showed that the CATSPER1 channel protein is responsible for the calcium influx during the hyperactivity phase of sperm after ejaculation. Thus, any variation in this protein channel can disrupt the hyperactivity phase, evidently leading to infertility (Avenarius et al. 2009)." This fragment of text should be corrected. Hyperactivation of ejaculated sperm cells (the spermatozoa movement is changed) is the result of their capacitation in the female reproductive system and enables the fertilization process. The authors used too much shortcut. References should be updated.

No development of the abbreviation PiRNAs, TDRD; "PIWI (comment of reviewer: gene or protein, italics means gene) and TDRD proteins are..."... HIWI genes... "(???)

The text should be read very carefully and checked in terms of spelling, style and abbreviations.

Is the topic of the review discussed comprehensively in the context of the current literature?

Yes

Are all factual statements correct and adequately supported by citations? Yes

Is the review written in accessible language?

Partly

Are the conclusions drawn appropriate in the context of the current research literature? Yes

Competing Interests: No competing interests were disclosed.

Reviewer Expertise: Basic and non-conventional seminological studies, genetic aspects of male infertility, sperm biology

I confirm that I have read this submission and believe that I have an appropriate level of 


\section{expertise to confirm that it is of an acceptable scientific standard, however I have significant reservations, as outlined above.}

\section{Author Response 29 May 2022}

\section{Temidayo S Omolaoye}

\section{Comment:}

The manuscript presented to me for review concerns the genetic causes of male infertility in the Middle East and North Africa (MENA) region. The topic discussed is important and still relevant due to its clinical significance and implications. Based on a literature review (different electronic databases were searched), the authors showed that genetic aberrations ( $Y$ chromosome microdeletion, deletion or gene mutation, gene polymorphism or copy number variation, chromosomal disorders, mitochondrial mutation) are a common cause of male infertility in the MENA region. The obtained research results are comprehensively presented in Table 1 and described in the text. Taking into account the obtained data, the authors rightly suggest that genetic tests should be part of the diagnosis of male infertility. Undoubtedly, such diagnostics will allow for proper therapeutic management, especially in the case of using ART. Generally, the text is written correctly in terms of its content. However, the manuscript requires revision prior to indexing.

\section{Response:}

The authors would like to thank the reviewer for the time and effort expended to review this work and thereby adding to the scientific merit of this study. Suggestions made by the reviewer have been addressed appropriately.

\section{Comment:}

The most important remarks are listed below:

Abstract: "...30\% of these cases remain idiopathic." This data should be updated. Idiopathic infertility accounts for 30-50\% of male infertility (Agarwal et al., 2019,2021).

\section{Response:}

The information has been updated to read "about $30-50 \%$ of these cases remain idiopathic".

\section{Comment:}

There is no information in the Introduction about idiopathic failure.

Response:

The below sentences have been inserted in the text to address idiopathic infertility, from line 51-56.

"It has been reported that around $60 \%$ of the total cases are attributable to the male factor, of which up to $50 \%$ are idiopathic (Agarwal et al. 2019, 2021). Unlike unexplained male infertility which sometimes is characterized with normal semen parameters, idiopathic male infertility is diagnosed in the presence of altered semen characteristics without an identifiable cause and the absence of female factor infertility (Hamada et al. 2011, Agarwal et al. 2019)".

Comment:

"Y chromone (?) microdeletion"; "...P or Q arm of..." should be $p$ arm or q arm

Response:

Corrected in the text. Line 135. 


\section{Comment:}

The content on the molecular structure of the $Y$ chromosome should also be presented in the form of a diagram (structure of the $Y$ chromosome with regions and genes marked).

\section{Response:}

A new diagram has been inserted in the text as Figure 3

\section{Comment:}

The caption under figure 2 should be corrected: "...the genetic alteration the genetic alteration."

\section{Response:}

The repeated sentence has been deleted.

\section{Comment:}

Information on ROS is contained in two sections: "Evidence of genetic mutations in the MENA region" and "Evidence of mitochondria mutation in the MENA region". I suggest that they be written exhaustively only in the section: "Evidence of mitochondria mutation in the MENA region". They should be expanded and superseded with the latest literature. The text includes many mental abbreviations.

\section{Response:}

We avoided focusing on ROS because several review articles have elaborated on the matter. However, we have cited more studies that discussed to topic in greater detail for further reference.

The sub-section addressing Evidence of Mitochondria Mutation in the MENA region has been updated. Line 388-401.

\section{Comment:}

Section: "CATSPER channel protein". "Avenarius et al. (2009) carried out a study to report the relationship between variation in the CATSPER1 channel and infertility amongst (???) Iranian men. The study showed that the CATSPER1 channel protein is responsible for the calcium influx during the hyperactivity phase of sperm after ejaculation. Thus, any variation in this protein channel can disrupt the hyperactivity phase, evidently leading to infertility (Avenarius et al. 2009)." This fragment of text should be corrected. Hyperactivation of ejaculated sperm cells (the spermatozoa movement is changed) is the result of their capacitation in the female reproductive system and enables the fertilization process. The authors used too much shortcut. References should be updated.

\section{Response:}

This section of the manuscript has been revised. Please see below and line $266-276$ in the text.

The study was able to identify insertion mutations, which led to premature stop codons and consequently variation in the CATSPER 1 protein (Avenarius et al. 2009). The CATSPER 1 protein is part of a tetrameric voltage gated calcium channel which are highly conserved in humans and mice. Carlson et al. showed the necessity of CATSPER 1 for $\mathrm{Ca}^{+}$entry into the flagellum and for $\mathrm{Ca}^{+}$mediated hyperactivated sperm motility (Carlson et al. 2003). Thus, an abnormality in the CATSPER 1 protein may hinder the calcium-mediated sperm functions. Once sperm enters the female reproductive tract, it undergoes the calcium mediated 
process of capacitation. When capacitation occurs successfully, the sperm is able to carry out its role in fertilization. Thus, it was suggested that variation in the CATSPER 1 channel may hinder the process of capacitation and consequently leading to infertility (Avenarius et al. 2009).

\section{Comment:}

No development of the abbreviation PiRNAs, TDRD; "PIWI (comment of reviewer: gene or protein, italics means gene) and TDRD proteins are..."... HIWI genes... "(???)

Response:

Statement has been revised appropriately.

\section{Comment:}

The text should be read very carefully and checked in terms of spelling, style and abbreviations.

Response:

The entire manuscript has been thoroughly proofread.

Competing Interests: Authors have no competing interest to declare.

The benefits of publishing with F1000Research:

- Your article is published within days, with no editorial bias

- You can publish traditional articles, null/negative results, case reports, data notes and more

- The peer review process is transparent and collaborative

- Your article is indexed in PubMed after passing peer review

- Dedicated customer support at every stage

For pre-submission enquiries, contact research@f1000.com 